\title{
Acadian biospeleology: composition and ecology of cave fauna of Nova Scotia and southern New Brunswick, Canada.
}

\author{
Max Moseley ${ }^{1}$
}

\begin{abstract}
:
Moseley M. 2007. Acadian biospeleology: composition and ecology of cave fauna of Nova Scotia and southern New Brunswick, Canada. International Journal of Speleology, 36 (1), 1-21. Bologna (Italy). ISSN 0392-6672.

The vertebrate and invertebrate fauna, environment and habitats of caves and disused mines in Nova Scotia and southern New Brunswick are provisionally catalogued and described, based on field collections made over many years. The area was glaciated and the subterranean fauna consists of non-troglobites all of which have arrived and colonised the caves during or following final recession of the Pleistocene glaciers. The statistical composition of the fauna at the higher taxonomic level is similar to that in Ontario, but is less species rich and there are some notable ecological and other differences. Porcupine dung accumulations are an important habitat in the region, constituting a cold-temperate analogue of the diverse guano habitats of southern and tropical caves. Parietal assemblages are, as in other cold temperate regions, an important component of the invertebrate fauna but here include species derived directly from dung communities: another parallel with tropical guano caves. An unanticipated finding is the number of non-indigenous species now utilising local caves. These appear to have colonised unfilled ecological niches, suggesting that post-glacial recolonisation of the subterranean habitat in Nova Scotia has been relatively delayed. Finally the general and regional significance of the subterranean fauna is briefly discussed.
\end{abstract}

Keywords: Cave fauna, Canada, Nova Scotia, New Brunswick, porcupine dung, guano caves, parietal, threshold fauna, introduced taxa, post-glacial, recolonisation.

Received 8 July 2006; Revised 10 October 2006; Accepted 31 October 2006

\section{INTRODUCTION}

The central focus of biospeleological research and thinking especially in North America has been those highly-adapted specialised troglobiontic animals which inhabit deep caves and subterranean waters in regions to the south of the maximum limits of the Pleistocene glaciations. Much less attention has been paid to the subterranean fauna of formerly glaciated northern regions of the continent, or to the many nonobligate species that occur in cave thresholds there and elsewhere.

The limits traditionally imposed by an emphasis on troglobionts to the exclusion of other fauna have long hindered progress in understanding hypogean fauna and ecosystems. However this is now changing. Most cave ecologists now accept the need to see subterranean communities in their entirety encompassing species at many different stages of adaptation (Gibert \& Deharveng, 2002), and evolutionary cave biologists increasingly recognise the value of non-obligate cavedwellers as empirical models of natural selection and

1) Research Associate, Nova Scotia Museum of Natural History, 1747 Summer Street, Halifax, Canada B3H 3 A6

(E-mail: moleslei@yahoo.ca) adaptation in the underground environment (e.g. Kane \& Culver, 1992).

Accordingly there is now a clear need for systematic field surveys and evaluation of the cave and groundwater fauna of neglected regions of the continent, particularly Canada.

The eastern region of Canada comprising Newfoundland, the Maritime Provinces (Nova Scotia, New Brunswick, Prince Edward Island), Quebéc, and Ontario has many areas of karst, and natural dissolution caves are known from all these provinces except Prince Edward Island. However there have been almost no specific or regional biospeleological surveys. The exceptions are a detailed study of the fauna and ecology of Frenchman's Cave, Nova Scotia (Calder \& Bleakney, 1965; 1967) and a general survey of caves and mines in southern Ontario (Peck, 1988).

The geographical area dealt with in the present paper, Nova Scotia and the southern part of the adjacent province of New Brunswick (Fig. 1), is the northern end of the Northern Appalachians region. The Maritime Provinces together with areas of eastern Quebéc are the Canadian part of the early French colony of Acadia; hence "Acadian" is a useful term often used in reference to this region. 


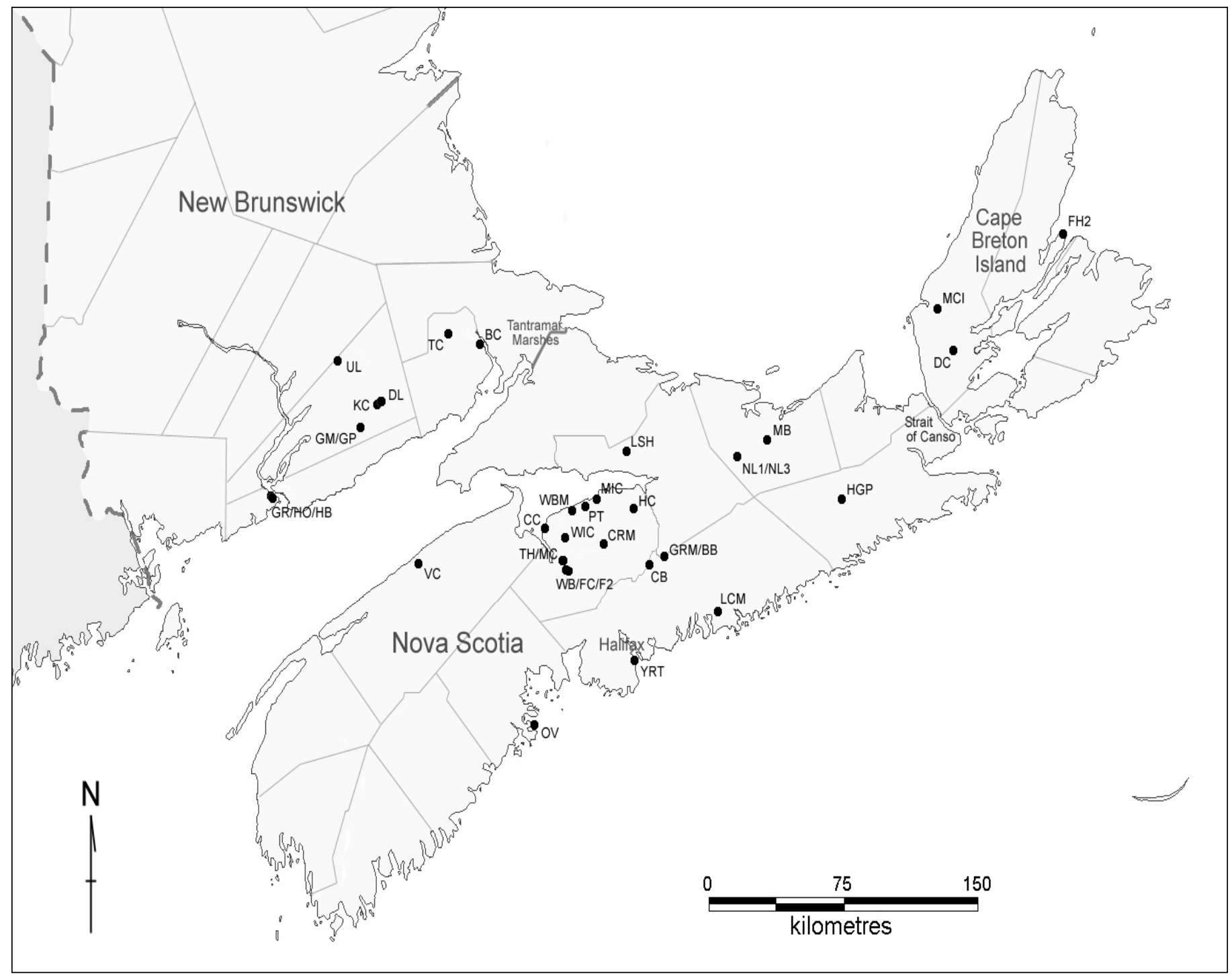

Fig. 1. Outline map of Nova Scotia and southern New Brunswick, to show location of study sites. [Provincial and county boundaries are shown by solid lines; the broken line represents the Canada-USA international border. Dots may represent more than one cave or mine. See text for key to alphanumeric codes.].

The area is cold-temperate, and somewhat low-lying with maximum elevations in Nova Scotia of $532 \mathrm{~m}$ and $446 \mathrm{~m}$ in southern New Brunswick. The whole of the present-day land area was subjected to multiple glaciations during the Pleistocene and was icecovered at the maximum of the last (Wisconsinian) glacial advance. The fauna and flora of the region is the result of immigration and recolonisation during and following the final retreat of the Wisconsinan glaciers, which is believed to have started $\sim 21,000$ years BP and to have been complete by $\sim 11,000$ years BP (King, 1996). Most species must have arrived from the south and west. Recolonisation of New Brunswick from these directions was relatively unrestricted by major physical barriers but immigration of many animals and plants into Nova Scotia is thought to have been constrained by the Tantramar Marshes, a narrow marshy isthmus which is the only land connection with New Brunswick: as a consequence the province is zoogeographically an island for many species (Fig. 1). The Strait of Canso physically further isolated Cape Breton Island until completion of the Canso Causeway in 1955 (Fig. 1). However there is evidence from present-day patterns of animal and plant distribution that some species may have recolonised Nova Scotia from the east by migration from an icefree Wisconsinian Atlantic Coastal Plain Refugium (Schmidt, 1986) or more likely from the emergent land areas which existed during the process of deglaciation (King, 1996). The existence of other late-Pleistocene refugia has also been proposed (e.g. Schmidt, 1986) but this remains highly speculative. In the historical period European contact resulted in the introduction of many exotic species through human migration and sea-borne trade.

The area has a number of exposed areas of sulphate (gypsum-anhydrite) and carbonate (limestone and dolostone) bedrock with underground drainage, springs, caves and other geomorphological karst features (Moseley, 1976; 1996: McAlpine, 1979). The southern part of mainland Nova Scotia has no significant karst but both gypsum and limestone caves are generally well-distributed throughout the rest of the region, with gypsum caves and karst predominating in Nova Scotia and limestone in New Brunswick. Dolostone karst is rare and no caves are known. 
Moseley (1996) gives maps showing the surface distribution of karst-forming rocks.

There are scattered notices of caves in various early geological survey reports, newspaper articles and other publications but the past forty years has seen the most intensive exploration and documentation. Approximately 50 dissolution caves are now documented in Nova Scotia and 20 in southern New Brunswick. All explored caves are small with few exceeding $250 \mathrm{~m}$ in length. The White Cave system (surveyed length $=515 \mathrm{~m}$ ) in New Brunswick; Hayes Cave $(365 \mathrm{~m})$ and Point Edward Cave (293m), both in Nova Scotia, are the largest. The existence of more extensive subterranean systems is inferred from surface patterns of sinks and springs (Moseley, 1996).

Both Nova Scotia and New Brunswick have long histories of underground hardrock mining and the many abandoned mines provide ecologically cave-like habitat.

Emerton (1917) reported the Cave Spider Meta ovalis (as M. menardi) in Nova Scotia, although not from caves. Two specimens in the Canadian National Collection (CNC 3437, 3438) collected in Gays River Gold Mine, Nova Scotia, in 1963 appear to be the earliest underground record. The first published notices of cave animals in the area are of hibernating bats: the Northern Long-Eared Bat (Myotis septentrionalis) was reported by Gould (1936) in a cave in Hants County, Nova Scotia. Bleakney (1965) later found Eastern Pipistrelle (Pipistrellus subflavus) at several Nova Scotia sites as well as making the first reports of the occurrence of the common Little Brown Bat (Myotis lucifugus) in caves and mines in that province. In New Brunswick, McAlpine (1976) reported $P$. subflavus for the first time (from a cave) and the same author (1979) summarized underground records of this and other bats. There is one sight record of the Big Brown Bat (Eptesicus fuscus) in a cave hibernaculum in Nova Scotia (Scott \& Hebda, 2004). Records of bats at underground sites in Nova Scotia have recently been collated by Moseley (in press).

There has been no systematic effort to document other vertebrates, but occasional records and observations have accumulated. North American Porcupine (Erethizon dorsatum) (Fig. 2) and their dung have been observed in most caves and a number of disused mines in southern New Brunswick and the mainland of Nova Scotia (Calder \& Bleakney, 1965; 1967; McAlpine, 1979; Moseley, 1998). Porcupine did not reach Cape Breton Island until completion of the Canso Causeway. They have since become established in the east of the island (Scott \& Hebda, 2004) but there are no reported sightings yet in island caves or mines.

Several other vertebrates have been sporadically recorded underground. McAlpine $(1977,1979)$ lists Mink (Mustela vison) scat, Smokey Shrew (Sorex fumeus), Deer Mouse (Peromyscus maniculatus) and a Beaver (Castor canadensis) den in New Brunswick. Beaver have also been seen in a Cape Breton stream cave (Sawatzky, 1986) and Raccoon (Procyon lotor)

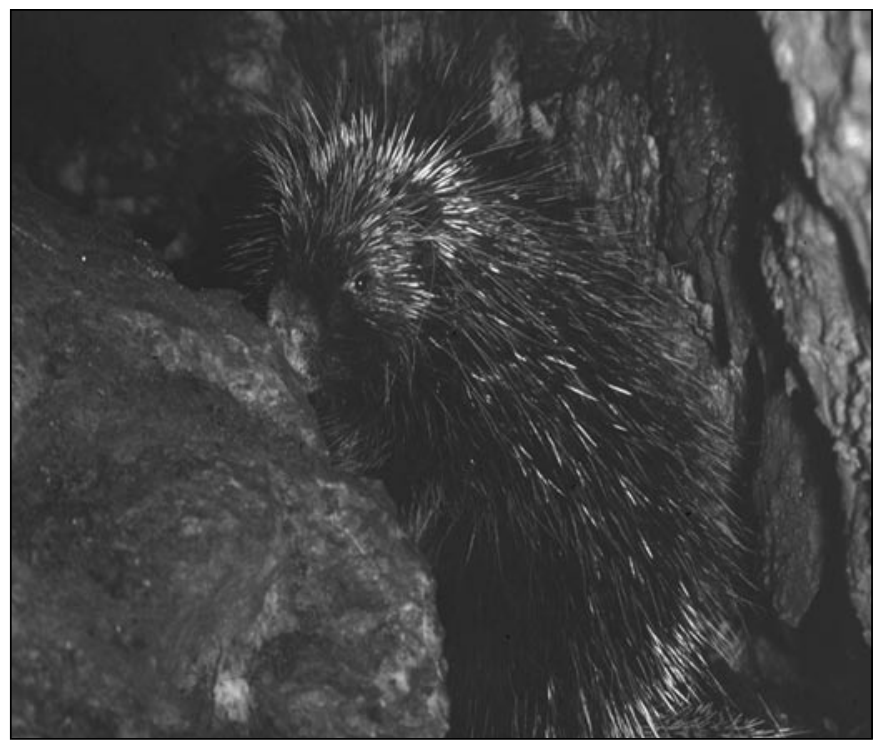

Fig. 2. Young adult North American Porcupine (Erethizon dorsatum) in den, dark zone, Cheverie Cave, Nova Scotia. (Photo: F. Vladi)

tracks were reported by Calder \& Bleakney (1967) in Frenchman's Cave. There are occurrence records of pallid Brook Trout (Salvelinus fontinalis) in limestone stream caves (Moseley, 1975; McAlpine, 1979) and Ninespine Stickleback (Pungitius pungitius) and Northern Redbelly Dace (Phoxinus eos) in Hayes Cave (Morris, 1985). Frog (Rana clamitans) tadpoles were collected in the threshold of Hayes Cave (Morris, 1985).

The first study of invertebrates was that of the terrestrial fauna of Frenchman's Cave, Nova Scotia (Calder \& Bleakney, 1965; 1967). Thirty-eight invertebrate taxa were reported from the threshold and deep threshold, the majority associated with decomposing porcupine dung accumulations. Acari were found to be numerically dominant in "poorly decomposed" dung samples, whilst Collembola became the most abundant microarthropods later in the ecological succession.

Broader, extensive rather than intensive, inventory of the regional invertebrate cave fauna began in the early 1970s with occasional sampling mostly as an adjunct to other underground work such as cave mapping, and continued through the 1980s and 1990s: a few of the records were published by the former Nova Scotia Speleological Society (Moseley, 1998 and references therein). Earthworms collected from several sites in New Brunswick were discussed by McAlpine \& Reynolds (1977) and a brief summary of the composition of other New Brunswick cave fauna was provided by McAlpine (1979). During 1997, a systematic field survey of Nova Scotia cave habitats and invertebrate fauna was performed (Moseley, 1998).

A few specialised studies have been published based on the collections: Marusik \& Koponen (1992); Moseley \& Hebda (2001); Moseley et al. (2006); and Majka et al. (in press). Christiansen \& Bellinger (1980, 1998) included records of Collembola in their comprehensive monographs on the North American collembolan fauna. 
Except for a preliminary unpublished study of Hayes Cave (Moore, 1963) investigation of the cave environment and ecology started with Calder and Bleakney's (1965, 1967) work, already referred to, in Frenchman's Cave. This was the first report of porcupine dung as a cave habitat in the region. McAlpine (1979) suggested that plant detritus and porcupine dung were the principle energy sources in New Brunswick caves. In Nova Scotia, Hayes Cave and its environmental conditions were investigated by the provincial Museum of Natural History (Scott, 1979; Morris, 1985). The presence of porcupine dung, plant debris, and scattered bat droppings $\left(<250 \mathrm{~m}^{-1}\right.$ of passage) as sources of energy was noted.

This paper reports the first comprehensive survey of cave fauna in Maritime Canada and the first general ecological survey of cave habitats and environmental conditions in any substantive geographical region of Canada. It also contributes to information about parietal assemblages, and adds to the very limited knowledge of the ecology of porcupine dung caves. An interim report was issued in manuscript as a museum Curatorial Report (Moseley, 1998)

\section{OBJECTIVES AND METHODS}

This study is intended as an overall assessment of the taxonomic composition and diversity of the invertebrate and vertebrate cave fauna of mainland Nova Scotia, Cape Breton Island and southern New Brunswick, together with a preliminary description of the ecology of the caves and mines. It is based on miscellaneous qualitative collections and ecological field records made over many years, complemented by a more representative survey in Nova Scotia in 1997. Terrestrial fauna was sampled by hand-collecting, baited pitfall traps, and Tullgren extractions of dung, litter and soil samples: aquatic fauna was taken by dip-nets, giant pipettes, sieves and kick sampling. Field notes were made of habitat, substrate, faunal associations, temperature and other environmental conditions. The stage of decomposition of porcupine dung was estimated using visual appearance, as described below. Specimens were killed, fixed and preserved using standard museum techniques and distributed to appropriate specialist taxonomists for identification. Voucher specimens are deposited in the collections of the Nova Scotia Museum and/ or retained by the relevant taxonomist. Published records, and unpublished records solicited from other workers, are incorporated into the text and tables.

There are faunal records (i.e. at least one taxon determined to genus or species) from a total of 26 natural caves and 11 abandoned mines and other artificial tunnels in Nova Scotia and New Brunswick. Study sites were distributed throughout the geographical area of investigation in order to obtain representative taxonomic coverage, although field work emphasized sites proximate to Halifax, and some collections were made in all seasons. The approximate locations of study sites are shown in Fig. 1, and a list follows:
NOVA SCOTIA: Black Brook Cave (BB), Cave-ofthe-Bats (CB), Lake Charlotte Gold Mine (LCM), Tunnels, York Redoubt (YRT), Gays River Gold Mine (GRM) [Halifax Co.]; Hayes Cave (HC), Woodville Ice Cave (WIC), Frenchman's Cave (FC), Frenchman's II (F2), Weir Brook Cave (WB), Minasville Ice Cave (MIC), Miller's Creek Cave (MC), Cheverie Cave (CC), The Honeycombs (TH), Peddlar's Tunnel (PT), Centre Rawdon Gold Mine (CRM), Walton Barite Mine (WBM) [Hants Co.]; Vault Cave (VC) [Kings Co.]; McLellan Brook Cave (MB), New Laing, adit \# 1 (NL1), New Laing, adit \# 3 (NL3) [Pictou Co.]; Diogenes Cave (DC); Mabou Cave (MCI) [Inverness Co.]; Fairy Hole II (FH2) [Victoria Co.]; Hirschfield Galena Prospect (HGP) [Guysborough Co.]; The Ovens (OV) [Lunenberg Co.]; Lear Shaft (LSH) [Colchester Co.].

NEW BRUNSWICK: Dalling's Cave (DL), Glebe Mine (GM), Glebe Pot (GP), Kitt's Cave (KC) [Kings Co.]; Greenhead Cave (GR), Howes Cave (HO), Harbell's Cave (HB) [St. John Co.]; Hillsborough Bat Cave (BC), Underground Lake (UL), Turtle Creek Cave (TC) [Albert Co.].

Descriptions and/or maps of the more important caves may be found in Moseley $(1976,1996)$ and Arsenault et al. (1997). For convenience collection sites are referred to hereinafter by their alphanumeric codes, as given above.

Taxa were categorized using the widely recognized Schiner-Racovitza categories of troglobite, troglophile, and habitual trogloxene for cavernicolous forms and accidental for strays and animals brought into the cave by floods and other chance events. The ecological status of taxa found underground is empirically difficult to determine and some decisions made about the status of those in this study are tentative. Taxa were assessed based on such evidence as the frequency of records from subterranean collecting sites and occurrence records of juveniles or larvae. Repeated long-term observations of a species from the same cave or mine and multiple collections from different sites are particularly valuable (Moseley, 1998). The known bionomics of a species elsewhere is also useful. All animals that are regularly found underground including threshold dwellers and guanophiles (see Discussion) are herein regarded as cavernicolous.

Sampling was not comprehensive enough to satisfactorily map geographical distribution or accurately ascertain seasonal occurrence of most cave-occurring taxa within the study area.

In this report threshold means that zone within a cave entrance where there is sufficient light to support vascular green plants, deep threshold means the low light area beyond the inner limit of the threshold and dark zone that part of the cave permanently in absolute darkness. 


\section{RESULTS}

\section{Fauna recorded}

The fauna records are collated and summarised in Tables 1 and 2 . Sixteen vertebrate and 170 invertebrate taxa, representing 12 and 99 families respectively, have been identified. An analysis of the recorded invertebrates by higher taxonomic group is given in Table 3.

Excluding accidentals, ectoparasites and those taxa for which ecological status could not be assessed, 11 vertebrate and 123 invertebrate cavernicoles (including guanophiles) were recorded in 8 and 72 families respectively. Sixty-five of these cavernicolous taxa (48\%) are categorized as habitual trogloxenes, 44 (33\%) as troglophiles, and $25(19 \%)$ as guanophiles. No troglobites were identified.

Of the cavernicoles 112 (84\%) are terrestrial animals, $22(16 \%)$ aquatic. Of the 112 terrestrial cavernicoles $38(34 \%)$ are categorized as parietal fauna.

$19(17 \%)$ of the terrestrial cavernicoles are almost certainly introduced non-indigenous species (allof them European in origin): the rest are Nearctic, circumpolar or cosmopolitan. All the non-indigenous species are invertebrates. Three further non-indigenous species which were collected are considered to occur only as accidentals in our caves.

In the case of aquatic invertebrate fauna, 20 cavernicolous taxa have been identified in the collections. Half of these are crustacea: Copepoda (5 species) or Ostracoda (5 species). Most of the rest are insect larvae: Odonata (3 species), Plecoptera (3 species), and Diptera (1 species). No introduced aquatic animals were found.

\section{Cave environment}

None of the accessible caves in the region have a constant temperature zone: all are subject throughout to surface environmental influences because of their small size, the presence of a stream, or through drafts due to multiple entrances. Radon gas concentrations in the inner areas of one of the largest caves, HC, (Morris, 1985) suggest almost stagnant air but even here the temperature changes seasonally, although the annual range is only $\sim 2{ }^{\circ} \mathrm{C}$. This site may be considered "deep cave" in the sense of Howarth (1988). Annual temperature range in the dark zone of a more representative small Maritime Canadian cave is $\sim 4^{\circ} \mathrm{C}$ (Fig. 3): many caves experience greater

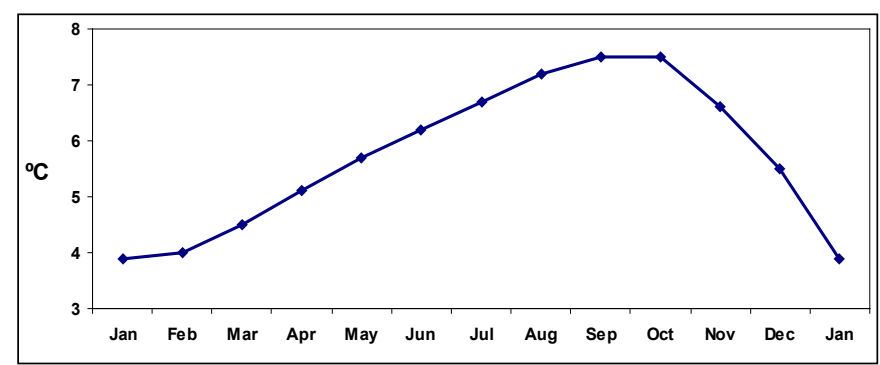

Fig. 3. Average monthly air temperature $\left({ }^{\circ} \mathrm{C}\right)$ in a representative Nova Scotia cave (dark zone in Frenchman's Cave). variation. During spring and early summer as the ambient temperature rises above that underground relatively cold air is retained inside caves, whilst warm air flows outwards in the autumn, thus skewing the annual curve (Fig. 3). In certain extreme special cases this effect results in so-called "ice caves" (see below). Maximum seasonal cave temperatures are recorded in September-October, minimum in January-February.

Eastern Canada experiences a very rigorous winter climate. Cave entrances are subject to severe low temperature conditions throughout the winter and there is often a build up of ice and snow. They are subjected to repeated freeze-thaw cycles: the average annual number of cycles $\left(-6^{\circ} \mathrm{C}\right.$ to $\left.+2^{\circ} \mathrm{C}\right)$ at Dartmouth, Nova Scotia has been calculated as 30 . As a result of this and ongoing dissolution of exposed rock, entrances are often almost filled in by blockfall and talus derived from within the threshold itself or from the cliff face outside (e.g. CB, HC, WIC, and FC). This physical barrier damps temperature fluctuations further inside resulting in fewer, perhaps only one, freeze-thaw cycle per annum in the deep threshold.

The mean annual temperature inside caves in central Nova Scotia is $\sim 5.7^{\circ} \mathrm{C}$. However it is lower at a few sites. The aspect and physical shape of certain caves cause atypical temperature conditions with ice and snow persisting into mid- or even late summer. Snow and ice which accumulate during the winter in WIC for example have been observed to survive until early August. The minimum air temperature measured inside the cave on 29 July 1997 was $2.5^{\circ} \mathrm{C}$, and $0.4^{\circ} \mathrm{C}$ was recorded a few centimeters below the floor surface on 6 August 1999. Such sites were often used historically for cold storage or as a source of ice and are known locally as "ice caves". However, none of the known local sites are true ice caves in the speleological sense of the term denoting a cave with permanent ice.

The temperature of standing water is usually within $0.5^{\circ} \mathrm{C}$ of the air in the immediate vicinity. There are several caves (e.g. CB, KC) with active stream sinks that modify the temperature. Temperature may also be affected by the presence of a spring. Some cave streams originate within the cave as eucrenal springs characterised by cold, clear sediment-free water with their temperature remaining within two degrees of the local annual mean. Examples are a small spring in $\mathrm{MIC}\left(4.3^{\circ} \mathrm{C}\right.$ in September 1995) and the F2 cave stream $\left(5.1^{\circ} \mathrm{C}\right.$ in July 1997$)$.

Cave waters in both limestone and gypsum caves are usually slightly alkaline: pH7.3-7.6. Acidic conditions may occur in stagnant or slowly flowing water where there are accumulations of porcupine dung or plant litter e.g. pH5.8 was measured in seeps with porcupine scat in WIC, pH6.5 in pools with plant flood debris in $\mathrm{CB}$. Due to the high solubility of calcium sulphate (i.e. $2.438 \mathrm{~g} \cdot 1^{-1}$ in distilled water $@ 10^{\circ} \mathrm{C}$ ) and the presence of other dissolved solids such as calcium carbonate, gypsiferous waters have high conductivity. Analysis of water samples from ponds in HC (Morris, 1985) showed conductivity readings of $2220 \pm 10 \mu \mathrm{S} . \mathrm{cm}^{-1}$. Samples of water from FC were so high in calcium 
sulphate that microcrystals of selenite precipitated out on cooling in a domestic refrigerator.

\section{Habitats}

Although characteristically small, caves in the region contain a diversity of terrestrial and aquatic eutrophic (dung), mesotrophic and oligotrophic habitats.

North American Porcupine (Fig. 2) dens are almost ubiquitous in caves and mines everywhere except Cape Breton Island. A den site is typically a small side passage, cavity or blind pocket within the deep threshold or dark zone occupied by a single animal. Cave dens always have an accumulation of faeces either as scattered pellets or more substantial accumulations (Fig. 4). In areas adjacent to the porcupine's access routes sustained inputs of dung sometimes result in deposits tens of centimeters deep covering several square meters of cave floor. These dung piles can occur anywhere from the threshold through to the cave dark zone. Etiolated seedlings are commonly present on fresh dung growing from seeds which have passed through the gut of the porcupine (Calder \& Bleakney, 1965) (Fig. 4). Decomposing dung fuels a varied community of bacteria, fungi, oligochaetes, insects, and other arthropods.

The dung habitat is non-uniform, varying microclimatically and qualitatively with diet, stage of decomposition, and environmental factors including moisture content, ecological zone within the cave, and temperature profile at each site. Fresh dung is acidic ( pH5.1) but in wet areas, such as where there is seepage water or under roof drips, the acidity is neutralized by the buffering effect of cave waters. Also, as observed by Calder \& Bleakney (1965), the decompositional sequence is accompanied by decreasing acidity, so that well decomposed and/or wet dung is slightly alkaline: $\leq$ pH7.3.

Because of the variability of $\mathrm{pH}$ and other empirically measurable factors, and because dung piles in the field often accumulate over many years, it was not possible to accurately determine the stage of decomposition of individual samples. However visual appearance is a useful approximate guide to the sequence. Fresh scat (Fig. 4) consists of scattered, ovoid, greenish-grey pellets with a mucoid surface. The mucoid material disappears rapidly (poorly decomposed). The pellets retain their shape and physical integrity for some time but turn darker brown in colour and the fibrous nature of their constituents becomes visible (moderately decomposed) (Fig. 5). In the later stages of decomposition they break down physically forming a material rather like dark well-weathered sawdust in appearance and consistency (well decomposed) (Fig. 6).

Invertebrate communities in porcupine dung piles are dominated by Acari, Collembola, dipteran larvae and enchytraeids (Figs. 7, 8). There are marked differences in the species composition and biomass of this community from site to site depending on microclimatic and qualitative factors. More than 35 terrestrial invertebrate taxa are recorded associated with dung in the Frenchman's cave system (FC +
F2), while the other extreme is represented by a remarkably simple ecosystem observed in GM where samples of well composted dung from the dark zone yielded only Protaphorura armata (Collembola) and enchytraeids. Qualitative observational evidence suggests that moisture content is the most important variable: both biomass and species diversity decrease in dry material. The abundance of Enchytraeidae in particular is affected by the moisture content and they are infrequent or absent in drier samples. Decompositional sequence is also a major factor. The general ecological succession reported by Calder \& Bleakney (1965) with Acari numerically most abundant in "poorly decomposed" samples and Collembola becoming dominant later has been observed at other sites. It was very apparent in GM where mites were abundant in moderately decomposed material (which also contained isotomid Collembola as well as $P$. armata and Enchytraeidae) but, as mentioned above, were absent from samples of well composted dung.

Acari are the most taxonomically diversified group in porcupine dung. Most have so far only been identified to genus or family. Parasitids (Parasitus, Eugamasus, Vulgarogasmus) are almost always abundant, and rhagidids (Rhagidia) are usually common. Other mites, some of which may be common to abundant at some sites, include Vegaidae (Vegaia), Zerconidae (Zerconopsis), Ascidae (Arctoseius), Ameroseidae (Epicriopsis), Eviphidae (Alliphis), Macrochelidae (Geolapsis), Pygmephoridae (Pygmephorus, Bakerdania), Tetranchidae (Bryobia), Acaridae (Acarus immobilis), Banksinomidae (Oribella) and various unidentified Uropodidae, Erynetidae and Histiostmatidae.

Collembolan populations are less diverse. They are almostalways dominated by onychiurids (Protaphurura, Tullbergia) and isotomids (Folsomia, Isotoma). Neelids (Megalothorax minimus), podurids (Willemia scandinavia) and entomobryids (Pseudosinella alba, Tomoceros minor) are found more infrequently.

Theinsect fauna of dung is dominated by nematoceran fly larvae. Larvae of Trichocera maculipennis and various sciarids are characteristically present and usually abundant (Figs, 7, 8). At least three different types of sciarid larvae are found, none of which have yet been matched with the adults recorded associated with dung in the caves. The latter include unidentified species of Bradysia, Lycoriella and Scatopsciara. Larvae of Limonia cinctipes, Chaoborus, Smittia, and Psychoda also occur in some samples, as do those of the brachyceran fly Leptocera. Adult Scatopsciara, Chaoborus and Leptocera have been observed attracted to fresh scat, presumably ovipositing. A few beetles are also found in this habitat. Larvae of Quedius s. spelaeus are often common in moderately decomposed dung, whilst the somewhat rarer adults are found under stones or running over the cave floor, almost always on or near dung (Moseley et al., 2006). The tiny guanophile Acrotrichis castanea is sometimes abundant, although it may be overlooked because of its size. Aphodius aleutus and Corticaria pubescens have been collected from dung: both occur in such 


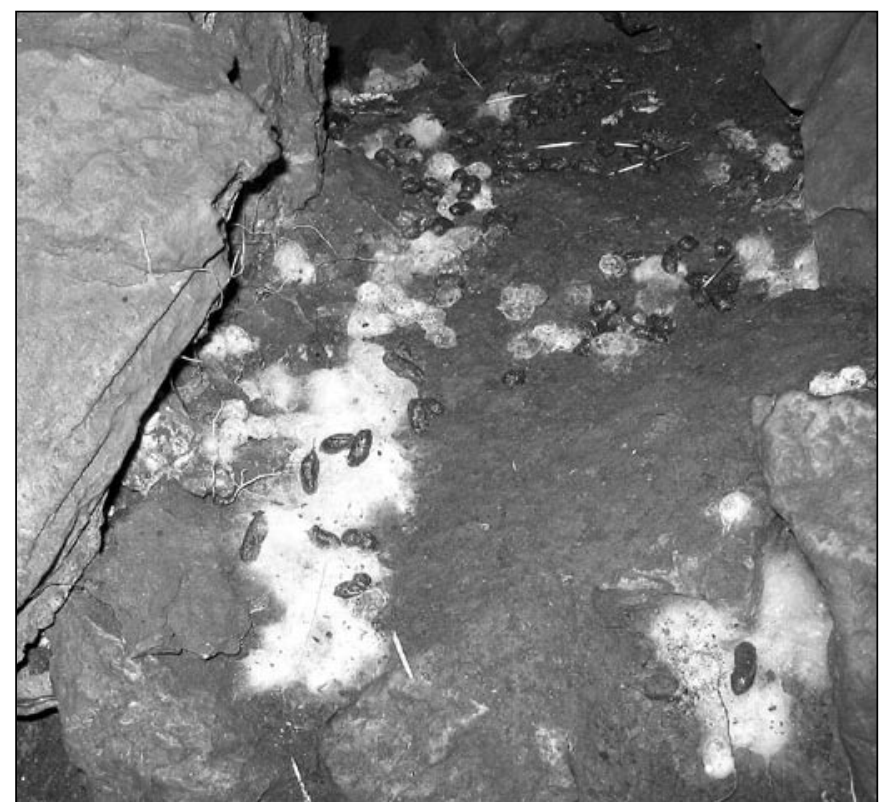

Fig. 4. Entrance of cave den occupied by the porcupine illustrated in Fig. 2. Numerous fresh droppings are clearly visible. The white areas are mats of fungal hyphae on older dung, and there are a number of etiolated plant seedlings growing from seeds which have passed through the gut of the porcupine. Several porcupine quills are also visible. (Photo: author).

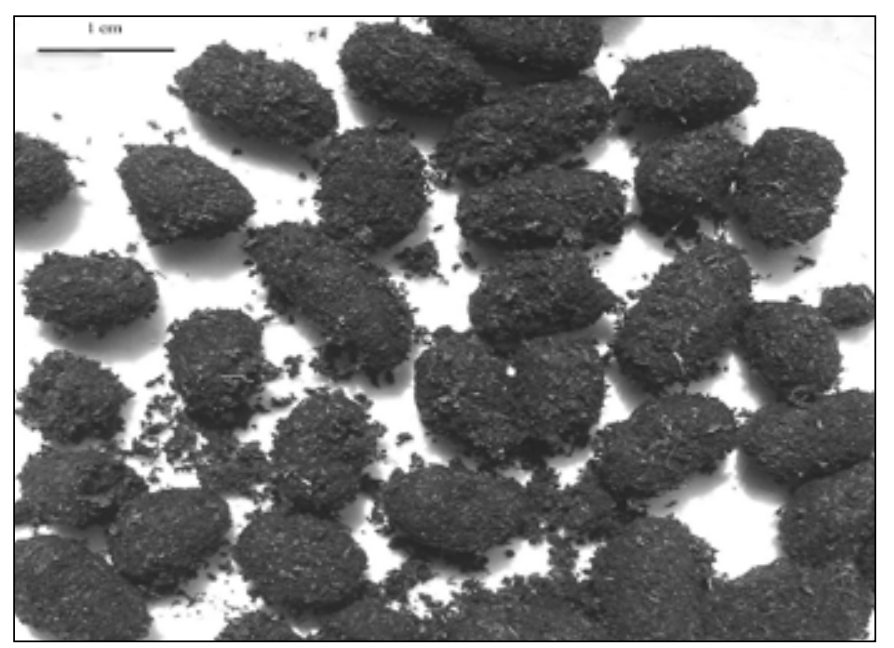

Fig. 5. 'Moderately decomposed' porcupine dung sample from Frenchman's II, Nova Scotia (Photo: author).

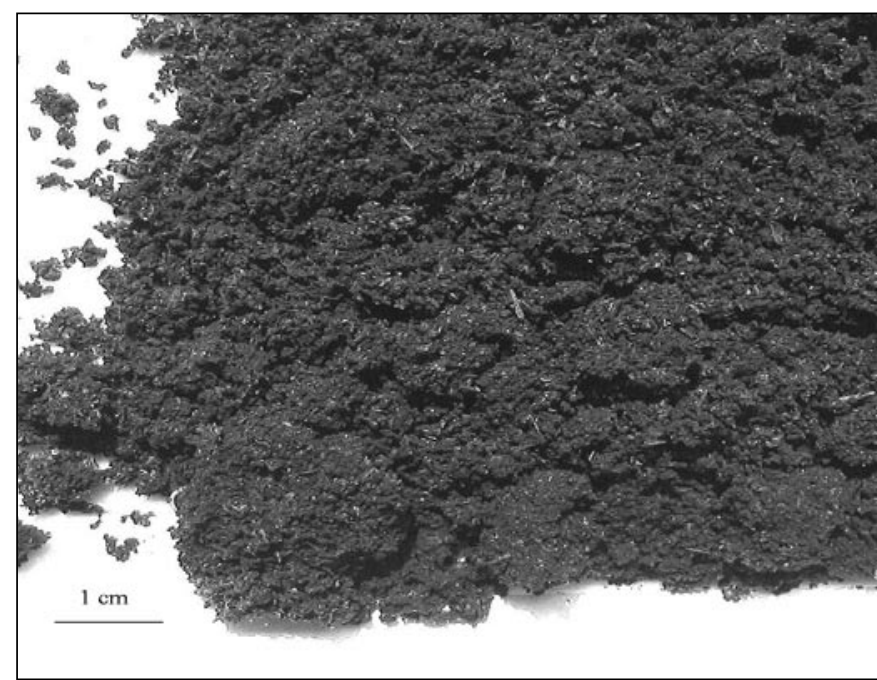

Fig. 6. 'Well decomposed' porcupine dung sample from Frenchman's II, Nova Scotia (Photo: author).

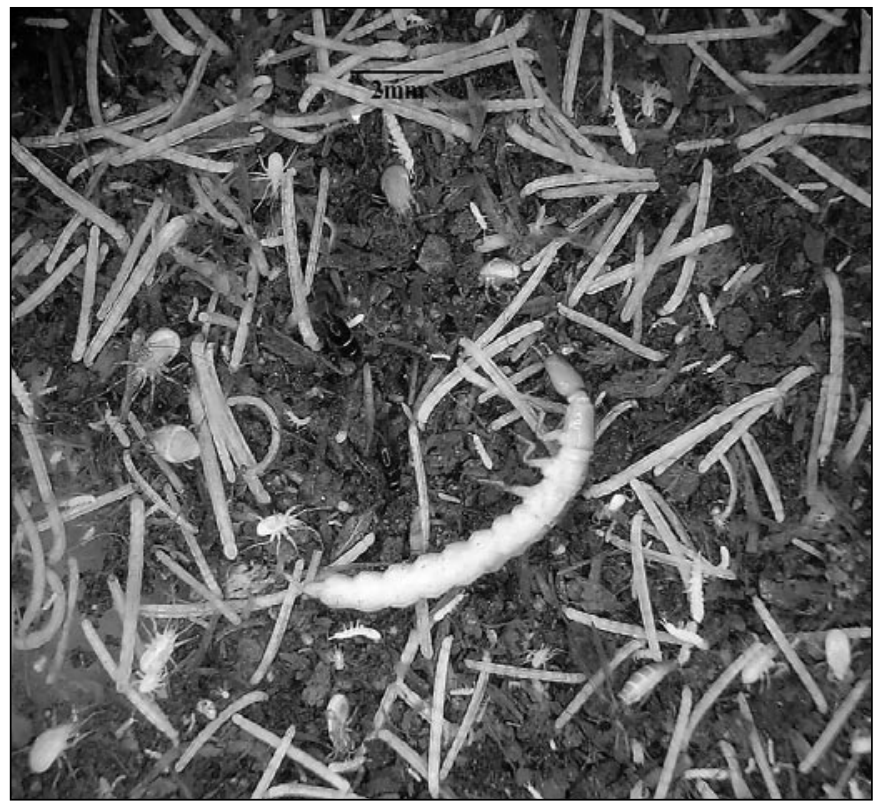

Fig. 7. Fauna extracted from a sample of 'moderately decomposed' porcupine dung, Frenchman's II, Nova Scotia, October 1997. Sciarid (Diptera) larvae are abundant, and there is an adult in the lower right. Parasitid mites and onychiurid Collembola (Protaphorura armata) are scattered throughout the field of view. The large coleopteran larva in the lower centre is Quedius s. spelaeus, and there are two adult ptilid beetles (Acrotrichis castanea) just above this. (Photo: C. Majka).

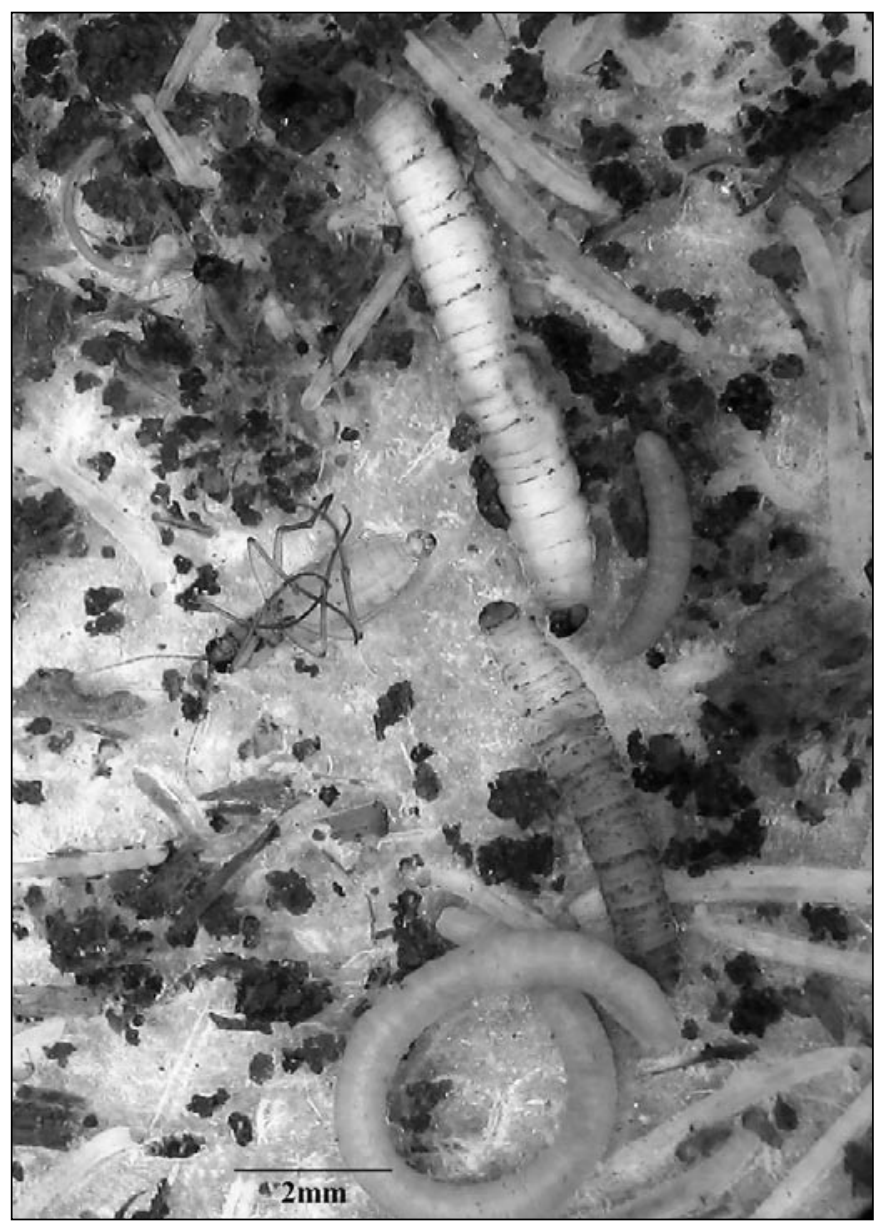

Fig. 8. Fauna extracted from a second sample of 'moderately decomposed' porcupine dung, Frenchman's II, October 1997. Trichocera maculipennis larvae (Diptera) and an enchytraeid are prominent. The adult fly near the centre is an unidentified sciarid. (Photo: C. Majka). 
habitats on the surface.

Other terrestrial invertebrates recorded associated with dung include Oniscus asellus (Isopoda), Lamyctes fulvicornis (Chilopoda), Proteroiulus fuscus, Ophyiulus pilosus, Polydesmus angustus (Diplopoda), and two linyphiid spiders Sisicottus montanus and Grammonota. Two earthworms (Dendrodrilus rubidus and Aporrectodea tuberculata) have also been collected, but as porcupine dung is almost unpalatable to earthworms it is at best a marginal habitat (McAlpine \& Reynolds, 1977).

Most local caves are at shallow depth and in consequence detritus and plant debris seep in from the surface through crevices. Leaf and other plant litter also often accumulate particularly in cave and mine thresholds. Damp, often rotting, support timbers are found in disused mines. Beavers denning in caves (e.g. $\mathrm{KC}$ ) store woods such as willow and alder as food. In stream sink caves such as $\mathrm{CB}$, freshets and flooding resulting from the spring snowmelt carry in plant debris and organic sediment.

The varied invertebrate community of vegetation litter and detritus includes Dendrodrilus rubidus, Aporrectodea tuberculata, and Eisenia rosea (Oligochaeta); Hypogastrura pseudarmata, Neanura muscorum, Willemia scandinavica, Protaphorura pseudarmatus, Isotoma caeruleatra, Isotoma $\mathrm{sp}$. nova? Pseudosinella collina, Sminthurides malmgreni, and Ptenothrix marmorata (Collembola); Quedius mesomelinus, Brathinus nitidus, and Gennadota canadensis (Coleoptera); various dipteran larvae; Parasitus, Eugamasus, Vegaia, Linopodes motatorius, Cocceupodes, Rhagidia, unidentified tetranchids, and Glycyphagus domesticus (Acari); and Discus catskillensis (Gastropoda). Flood debris is often rich in many otherwise unexpected aquatic stages of insects and other accidentals. Most are dipteran larvae e.g. Tipula, Erioptera pilipes, and Chrysops.

Many flies and other insects together with a few other arthropods and gastropods occur regularly on cave walls and ceilings. Several arthropods (Oniscus asellus [Isopoda], Polydesmus angustus [Diplopoda]) and gastropods (Arion, Deroceras laeve, and Trichia hispida) are commonly found within or near the threshold but almost never further inside. With the exception of these this assemblage tends to be richest both in number of species and in number of individuals in the deep threshold, but it extends into the dark zone. The species composition changes seasonally. Diptera predominate: there is an especially species rich fauna of mycetophilids (Boletina, Bolitophilia, Rhymosia, Exechia, and Exechiopsis) and helomyzids (Scoliocentra, Helomyza, Amoebaleria, and Tephrachlamys). By far the most numerically frequent Diptera in these caves are Trichocera maculipennis and various sciarids: adults of these flies are common in this assemblage. Culex females are abundant at many sites in winter. Other common flies are Limonia cinctipes, Chaoborus, Psychoda and Leptocera. Infrequent flies include Dolichopeza, Anopheles and Peromyia. As already mentioned the larvae of L. cinctipes, T. maculipennis, Chaoborus, several unidentified sciarids, Psychoda, and Leptocera live in porcupine dung. Other insects and arachnids found on cave walls include Ceuthophilus brevipes (Orthoptera); Scoliopteryx libatrix and Triphosa haesitata (Lepidoptera); Nelima elegans (Opiliones); Meta ovalis and Nesticus cellulanus (Aranea). One gastropod, Zonitoides arboreus, is found further inside than other gastropods.

Oligotrophic habitats are uncommon in caves in this region. They are more usual in limestone caves than in gypsum but can occur in the latter (e.g. F2) where they typically comprise areas of pebbles, gravel and/or sand adjacent to a fast-flowing stream or underground cold spring. Most terrestrial taxa recorded from such sites are Collembola: Heteromurus nitidus, Arrhopalites hirtus, and Arrhopalites nr. pygmaeus. Allajulus latestriatus (Diplopoda) and several unidentified Acari have also been collected.

The pool surface association comprises various Collembola (Protaphora cf. boedvarssoni, Folsomia candida, Isotoma sp. nova? Heteromurus nitidus, Pseudosinella alba and Arrahopalites hirtus), occasional Symphyla (Scutigerella), and a number of different unidentified Acari. A psocopteran (Liposcelis) was collected at one site.

Aquatic habitats comprise standing water, ranging from small pools on mud floors (e.g. CC) to lakes (e.g. HC); running water, ranging from tiny seeps and rivulets (e.g. WIC) to large streams (e.g. $\mathrm{KC}$ ), and interstitial water. Cave streams may originate from the surface, or from an underground spring. In most gypsum caves there are substantial deposits of finegrained chocolate-brown sediment representing the insoluble residue of gypsum dissolution.

These aquatic habitats support a diverse fauna dominated by copepods (Acanthocyclops spp., Eucyclops agilis, Diacyclops crassicaudis, Paracyclops poppei, and Macrocyclops albidus) ostracods (Pseudocandona albicans, Cypria, Cavernocypris, Cypridopsis, and Fabaeformiscandona wegelini), microdrile oligochaetes and aquatic insect larvae: particularly Odonata, Plecoptera and chironomid Diptera. Stonefly nymphs are common and display considerable taxonomic diversity: unidentified capnids, Amphinemura (Nemouridae), Taeniopteryx (Taeniopterygidae), Haploperla (Chloroperlidae) and unidentified perlids have all been collected, mostly from the threshold although Haploperla can live further inside in cold streams. Dragonfly nymphs (Aeshna, Macromia) are found frequently enough in cave thresholds to be considered habitual trogloxenes in that habitat. Planarians may also be present in pools in cave dark zones, and a water-beetle Agabus larsoni has been collected from dark zone pools and streams in both gypsum and limestone caves and may be habitual. Various other invertebrates may be present in cave pools near the entrance, sometimes straying well into the dark zone, but most of these are essentially part of the threshold fauna or accidentals. The leech Helobdella papillata and another waterbeetle $A$. semivittatus are examples of the latter.

Haploperla sp. nymphs (Plecoptera) and Simulium 
sp. larvae (Diptera) occur in the oligotrophic eucrenal streams arising from underground cold springs.

There are occurrence records of three fish. Healthy looking Brook Trout (Salvelinus fontinalis) are sometimes seen in clear well-oxygenated streams well inside the dark zone in limestone caves. The Ninespine Stickleback (Pungitius pungitius) is at home in the thresholds of gypsum caves in large pools that have a connection with outside waters. It does not however stray far into the dark zone. A population of Northern Redbelly Dace (Phoxinus eos), was observed in $\mathrm{HC}$ for several years, but this fish has not been seen in any other cave.

Several different food inputs support animal communities in aquatic habitats. Dead insects are an important energy source. Insect corpses, especially Diptera, at times accumulate in large numbers on and in cave pools. A sample collected from a pool in F2 in October yielded Trichocera maculipennis, Leptocera, numerous sciarids and several Quedius s. spelaeus larvae and adults. These insects originate from the dung fauna and thus aquatic ecosystems are indirectly supported by porcupine dung. Dung may also be present as scattered droppings, or, sometimes (e.g. PT and $\mathrm{GM}$ ) in substantial accumulations. Associated fauna includes planarians, aquatic microdriles, copepods (Acanthocyclops venustoides) and dipteran larvae. Bat droppings never form substantive accumulations: Scott \& Grantham (1985) observed cyclopoid copepods associated with droppings in ponds in $\mathrm{HC}$ and Moseley (unpublished) made the same observation in MC.

Plant flood debris and other detritus carried in by sinking streams is also an important source of food in some caves. This input tends to be seasonal, with most material being brought in by spates during the spring snowmelt. The aquatic invertebrate fauna found associated with such material is more diverse than where this food supply is not available, but it is difficult to distinguish resident cavernicoles from the many accidentals carried in along with the plant debris.

Beaver living quarters with stored willow and alder were found well inside the dark zone of KC (McAlpine, 1977). The site had been abandoned when it was examined in 2005.

Sites that meet appropriate microclimatic and morphological conditions and are relatively undisturbed by human traffic are used by four species of insectivorous vespertilionid bats as winter hibernacula. Three gregarious non-migratory species (Myotis lucifugus, M. septentrionalis and Pipistrellus subflavus) commonly use caves and mines as winter hibernacula, entering in late September/early October and leaving in early summer. Another non-migratory bat Eptesicus fuscus preferentially hibernates in buildings but may occasionally use underground sites (Scott \& Hebda, 2004). Hibernating P. subflavus are solitary and only the two Myotis spp. form hibernating colonies. The known colonies are not large: the population (>95\% Myotis spp.) in the largest known hibernaculum is estimated to be <10,000: other sites rarely contain more than a few hundred animals.

Small numbers of male bats also sometimes roost in underground sites in mid-summer, whilst in latesummer (September and early October) bats roost in caves and mines by day and continue feeding at night in preparation for hibernation. Bat droppings that accumulate in late summer have been seen in several caves, but significant deposits of bat guano do not form. Acari and Collembola are often present on bat droppings (Scott \& Grantham, 1985).

Other mammals, amphibians and fishes occasionally reported from caves and mines are listed in Table 2.

Wright (1979) reported two species of ectoparasitic Acari and one siphonapteran collected ex-Myotis from non-cave sites.

\section{DISCUSSION}

\section{Composition of the invertebrate fauna}

The invertebrate fauna is in many ways similar in composition to that of Ontario and northern Europe but there are also some important differences.

Taxonomically it is dominated by insects and Collembola, followed by arachnids. Mollusca form a small but significant component that is often overlooked. These findings are consistent with those from the two previous eastern Canadian regional surveys (Table 3). Pooled results from all three studies indicate that in eastern Canadian caves, insects and Collembola typically constitute $\sim 60 \%$ of all invertebrate species, arachnids $\sim 20 \%$, molluscs $\sim 5 \%$ and all other invertebrates $\sim 15 \%$.

In the taxonomic groups Diptera, Aranea, Opiliones and Mollusca, as well as in the overall total of all taxa, the number of taxa recorded in the present survey is significantly lower than that collected in southern Ontario caves (Peck, 1988) (Table 3). This almost certainly reflects lower species diversity in the present survey area, particularly Nova Scotia which has a somewhat impoverished provincial fauna due at least in part to the Tantramar Marshes zoogeographical barrier. More intensive collecting will certainly significantly extend the New Brunswick list. The four taxonomic groups referred to are dominated by species from the parietal assemblage (see below) which constitutes a major faunal association in caves and mines in both Ontario and the Maritimes.

In the Acari and the Collembola the opposite is the case: the local cave fauna is more species rich than that of Ontario. Both these taxonomic groups are wellrepresented in communities living in porcupine dung, a habitat not reported in southern Ontario caves by Peck (1988).

In general, there is little specific overlap between the invertebrates found associated with different organic substrates. Vegetable litter is generally richer in terrestrial troglophiles than is porcupine dung. Rotting timbers in abandoned mines and elsewhere provide a habitat for a few earthworms, Acari and Collembola, but the fauna found in them does not appear to be very rich in this geographical area. Some invertebrate species appear to be almost exclusively associated 
with oligotrophic sites e.g. Heteromurus nitidus and Arrhopalites hirtus.

As in virtually all cave ecosystems porcupine dung communities are simplified with two fundamental trophic levels, primary producers and herbivores, absent. They differ from most other cave guano ecosystems in that the porcupine is herbivorous feeding preferentially on the cambium of trees, especially conifers. The remaining two classic trophic levels, decomposers and predators, are easily recognized. This is usually true of cave guano communities but may not be the case in oligotrophic cave communities where decreasing resources are associated with blurring of the distinction and even disappearance of obligate predators in favour of omnivores (DeHarveng \& Bedos, 2000). Quedius s. spelaeus adults and larvae and various predatory mites (e.g Alliphis, Geolapsis) are the common predators in porcupine dung communities.

There is an unusual suite of parietal species that is ecologically fundamentally different in its nature from the original sense of Jeannel (1926). It constitutes a distinct faunal component derived directly from the porcupine dung fauna. The larvae of several Diptera (Limonia cinctipes, Trichocera maculipennis, Chaoborus, various sciarids, Psychoda, and Leptocera) live in porcupine dung, and adult Scatopsciara, Chaoborus and Leptocera have been observed apparently ovipositing in very fresh pellets, thus, unlike almost all the "traditional" parietal insects, these Diptera are probably able to complete their life cycle underground. This is reminiscent of the situation in the humid tropics where there is frequently an assemblage of arthropods derived from guano communities on cave walls deep inside caves (Deharveng $\&$ Bedos, 2000).

A 'parietal association' in Jeannel's (1926) sense can also be readily recognized in Maritime caves. It is very similar to that found in Ontario (Peck, 1988), northern Europe and other cold temperate regions of the world and comprises the associations of arthropods living or resting on cave walls and other rock surfaces together with the spiders that prey upon them. Parietal predators tend to be specialized forms found only in this and similar dark humid habitats such as cellars, and are usually considered to be troglophiles. Most of the parietal association however consists of habitual trogloxenes that are using the habitat temporarily for shelter, summer aestivation, hibernation, overwintering, or other purposes that are not yet fully understood. Adult Diptera predominate both in number of species and number of individuals. Overwintering fauna includes Nelima elegans (Moseley \& Hebda, 2001), female Culex spp. and some species of Bolitophilia, Rymosia and Tarnania (Mycetophilidae). Some of the Exechiini (Mycetophilidae) along with the adult Limniphilidae occasionally seen in New Brunswick caves are probably there for summer aestivation. Two spiders (Meta ovalis and Nesticus cellulanus) specialise in predating other parietal fauna. Ceuthophilus brevipes uses caves and mines for shelter and forages outside. There are also two moths Scoliopteryx libatrix and Triphosa haesitata. Adult helomyzids (Scoliocentra, Helomyza, Amoebaleria, and Tephrachlamys) are common and are present year round but their purpose in entering caves is unknown: their larvae are not found in this habitat.

Several other arthropods (Oniscus asellus [Isopoda], Polydesmus angustus [Diplopoda]) and gastropods (Arion, Deroceras laeve, Trichia hispida) are commonly found on rock surfaces in the threshold but rarely much further in. Another gastropod Zonitoides arboreus appears to be somewhat more cavernicolous in its behaviour than the other recorded mollusca, and is sometimes found well inside the dark zone. These species are also common in dark moist habitats on the surface and unlike the animals traditionally included in the parietal association are apparently not in caves for a specific purpose. However, because they are characteristically present in this habitat and the arthropods are preyed upon by parietal spiders, it seems logical to include them as parietal fauna.

The subterranean aquatic fauna is undercollected and the statistical dominance of terrestrial (80\%) versus aquatic $(20 \%)$ taxa in the lists certainly partly reflects this collecting bias.

\section{Mammals, amphibians and fishes}

Most of the recorded vertebrates enter caves for definite purposes and thus may be considered to be habitual trogloxenes.

Two fishes, Salvelinus fontinalis and Pungitius pungitius, are seen frequently enough to suggest that in behaviour they are the most cavernicolous vertebrates in the region. Beaver as well as Porcupine use underground sites as dens. McAlpine (1977) reports records of beaver in caves from Alabama, Missouri and New Brunswick. Two small mammals, the Smokey Shrew (Sorex fumeus) and the Deer Mouse (Peromyscus) are known from research elsewhere to predate hibernating bats in caves (Banfield, 1974; Trevor-Deutsch, 1973) and are thought to enter local caves primarily for this purpose, whilst Raccoon and Mink enter them to forage.

The remaining vertebrates are probably accidentals. This is certainly the case for the adult frogs seen occasionally, perhaps entering during flooding. They have however been observed to survive for some time where a stream brings in food and offers suitable habitat (e.g. CB). Phoxinus eos was observed in $\mathrm{HC}$ for several years, but this fish has not been seen in any other cave and collected specimens were pallid and undernourished. A single extra-limital winter record of the migratory bat Lasionycteris noctivagans in PT probably represented a stranded storm-driven animal (Hebda, pers. comm.)

\section{Energy inputs: porcupine dung}

Porcupine and extensive deposits of their dung were first reported in caves in California (Graham, 1962). Calder \& Bleakney $(1965,1967)$ investigated 
the ecology of a porcupine-inhabited cave in Nova Scotia. Despite the wide distribution of the porcupine in North America the ecological significance of the porcupine dung habitat in caves has been overlooked or neglected. Graham (1962) stated that it was poor in invertebrate life. In a recent review of cave guano communities Gnaspini \& Trajano (2000) do not mention porcupine dung.

Substantial and sustained inputs of porcupine dung are the principle energy source supporting subterranean communities in New Brunswick and mainland Nova Scotia. These communities often display considerable species diversity. This is well illustrated by the St. Croix group of caves $(\mathrm{FC}+\mathrm{F} 2+$ WB) in Nova Scotia where some 89 taxa in 64 families have been identified, and is similar to many caves in the humid tropics where inputs of externally derived organic energy sources such as bat and cricket faeces support some of the most diverse cave ecosystems known (Gunn et al., 2000).

There are further ecological and faunal similarities with tropical guano caves. Although species-rich in comparison to other cave habitats, guano communities are in general simpler than those above ground (Gnaspini \& Trajano, 2000). Calder \& Bleakney (1965) demonstrated that the microarthopod fauna of $\mathrm{FC}$ is less diverse than that of nearby epigean habitats. Acari, as noted by Gnaspini \& Trajano (2000) in Brazil and elsewhere, are the most diversified group followed by Collembola. Mites are almost never dominant organisms in caves except in guano. The presence of an unusual parietal association derived directly from dung communities has already been referred to.

Accordingly this fauna can be seen as a rare coldtemperate North American analogue of tropical guano cave faunas. It must be emphasized that porcupine dung does not only directly support a guanobious fauna, but indirectly contributes substantially to other aquatic and terrestrial communities through the export of this fauna to other areas of the cave. The habitat thus has a more important status regionally, biospeleologically and as a reservoir of significant species diversity than hitherto recognized.

Historically, the guano habitat has not been seen as a "true" cave habitat and guanophiles have been categorized as "false cave-dwellers" (see e.g. Gnaspini $\&$ Trajano, 2000 and references therein). This view can be challenged as an extreme extension of the $a$ priori assumption that the cave environment is per se oligotrophic (itself an extension of the "troglocentric" focus briefly discussed in the Introduction). In fact, dismissal of the guano fauna in tropical caves seems to be at least in part an unconscious derivation from a belief, now known to be false, that there were no or very few troglobites in the tropics.

Troglobites are in fact not restricted to oligotrophic habitats. In Hawaii a rich fauna of specialized troglobites is found in the food-rich habitat provided by tree roots penetrating cavities in lava flows (Howarth, 1972). Some animals which are dependent on guano are traditionally accepted as troglophiles. This is almost certainly the case for instance with
Trichocera maculipennis, a circumpolar fly which is distinctly uncommon in surface habitats (Jefferson, 1981). It also seems somewhat illogical to exclude organisms that complete their life cycle underground as not cavernicolous whilst accepting those which for example merely use caves as temporary seasonal shelter. Finally, in order to reach and colonise guano piles organisms must be able to orient and survive in the wider cave environment (Gnaspini, 1992).

Thus, as proposed by Gnaspini (1992), guano should be treated simply as a substrate within a cave. All animals regularly found in and utilizing caves and related subterranean habitats ought to be classified as cavernicolous. Those guanophiles regularly occurring in subterranean habitats should be treated as one ecological category of cave fauna.

\section{Other energy inputs}

Vegetable debris, detritus and flood debris are significant food sources. They are presumed to be the main energy source in Cape Breton sites, where the porcupine is absent. Spring snowmelt flood debris constitutes a special habitat because it is seasonally pulsed. Rotting timbers are available at some sites, especially abandoned mines.

Insectivorous bat droppings are only of incidental importance as a food source, being localized and never forming substantial guano deposits. Where bat colonies occur they are small and droppings only accumulate in hibernacula for a few weeks during the autumn.

\section{Seasonality}

Circannual rhythms in cavernicoles have not been observed or investigated in the Canadian Maritimes. However the cave communities are subject to several seasonal environmental changes and cues. These include annual temperature cycles, pulsed inputs of organic matter into stream caves during the spring thaw and bat droppings in late summer. The composition of parietal assemblages is seasonal.

\section{Origin of the subterranean fauna}

The present survey indicates that the subterranean fauna of the region consists of communities of nonobligate species which have all arrived in the area and colonised hypogean habitats at various different times and via several routes during the past $\sim 11,000$ years, or perhaps in some cases earlier during deglaciation ( 21,000-11,000 BP).

No convincing example of a preglacial survivor has been found. The apparently disjunct distribution of $Q$. s. spelaeus suggests that this troglophilic beetle may have arrived from the emergent land areas that existed on the present-day Atlantic continental shelf during deglaciation (Moseley et al., 2006) but evidence based on faunal distribution is always difficult to interpret. The subterranean aquatic fauna needs more sampling as it is possible that one or more aquatic troglobites 
(stygobites) could have survived and reinvaded Nova Scotia groundwaters from Atlantic refugia. An unidentified species of Cavernocypris (Ostracoda) may hint at this possibility. Stygobitic amphipods of the genus Stygobromus are found on Vancouver Island and on offshore islands as far north as southeastern Alaska (Shaw \& Davies, 2000) and in glaciated regions of Alberta (Holsinger, 1980; Bousfield \& Holsinger, 1981).

One of the most interesting findings is the number of recent invasive non-indigenous taxa present in terrestrial cave communities. Of the cavernicolous terrestrial invertebrates $17 \%$ are probably European in origin (Table 1). Notable examples are the European threshold troglophile Nesticus cellulanus which is now established here, being found in cellars and similar dark damp places in the region, and the springtail Folsomia fimitaria. Records from FC are the first cave records of $N$. cellulanus in North America (Ewing, pers. comm.) and the same cave is the only confirmed North American locality for F. fimitaria (Christiansen \& Bellinger, 1980). It is also worth noting that specimens of the circumpolar Protaphorura armata (Collembola) from local caves are morphologically very similar to European examples from anthropogenic (agricultural) habitats (Pomorski pers. comm. 2006) and thus may represent another non-indigenous population.

Some care must be taken in accepting a taxon as nonindigenous. Some North American species previously thought to be co-specific with European animals have later been found to be distinct, and there are examples in the Acadian cave fauna. The spider Meta ovalis was distinguished from the European $M$. menardi only recently (Marusik \& Koponen 1992) and the widespread North American collembolan Folsomia stella was long confused with the morphologically very similar Old World F. fimitaria (Christiansen \& Bellinger, 1980). In other cases species previously thought to be introduced have later been shown to be native e.g. the earthworm Dendrodrilus rubidus (Schwert, 1979). Nevertheless, taken as a whole, the list of probable introductions is convincing.

The eastern Canadian seaboard has been subject to European exploration and colonization since Viking times, and has long been known as the probable point of introduction of many exotic invertebrates as a consequence of human migration and trade. Many of these are now widespread in surface habitats. Apparently a subset of "pre-adapted" species that have arrived and successfully established in the Maritimes has subsequently been able to enter and survive in subterranean habitats here.

Many of the invasive species were collected in FC and/or F2 (Table 1), but it is uncertain whether this is related to the fact that these caves are located in one of the earliest areas of Acadian French settlement in Nova Scotia or is a result of collecting bias.

Although recent work with epigean invasive species elsewhere suggests that many have colonized environments that are radically different from their sources (Lee, 2002) no evidence of this has been found in our non-indigenous cave-inhabiting fauna: all the introduced species listed in Table 1 are also reported either as common in caves (as troglophiles or habitual trogloxenes) or as guanophiles in their region of origin.

There can be little doubt that rather than competing with established fauna, some or most of these exotic species are exploiting empty biotopes in the subterranean environment. In the case of the Isopoda and Diplopoda there are no native species in the lists, all are introductions. Most of the cave-collected earthworms and mollusca are non-indigenous taxa, and almost half the terrestrial beetles are European in origin. The widespread Nearctic threshold spider Nesticus pallidus was not found: it is replaced in this habitat by the closely related European $N$. cellulanus.

The existence of previously unfilled ecological niches must be at least in part due to the taxonomic impoverishment of the Nova Scotian fauna resulting from zoogeographical isolation of the province. Several authors (e.g. Chapman, 1993) have pointed out that cave faunas in formerly glaciated regions are in an early dynamic phase of recolonisation and adaptation. It appears that recolonisation of hypogean habitats in Nova Scotia has been relatively even more delayed and thus that subterranean communities are in general at an earlier stage of this process than those in other otherwise similar geographical areas.

In Maritime Canada we also have the unusual situation where there are eutrophic dung communities in this early phase: guano caves in the humid tropics are ancient systems never subjected to glaciation. It is believed that the porcupine is a relatively late postglacial arrival in Nova Scotia (Calder \& Bleakney, 1965).

Colonisation, adaptation and speciation in cave faunas can be rapid processes that may be taking place on a human timescale. Lava tubes on the geologically very young island of Hawaii, which is less than 700,000 years old, already harbour a rich fauna of highly-adapted troglobites consisting of representatives of native groups in the process of adaptive radiation (Howarth, 1972).

\section{Significance of the subterranean fauna}

Before 1970 only a few local caves were well-known to naturalists and cave ecosystems in the region were assumed to be isolated, localised and restricted. Maritime Canadian cave fauna was not recognised as ecologically significant. However, subsequent documentation of many more caves together with the important insight from elsewhere that most so-called "cave" fauna is not restricted to caves (an anthropocentric concept) as such but is widely distributed throughout mesocavernous voids and the MSS ("milieu souterrain superficial") (Juberthie, 1984 and references therein) means that we must now recognize subterranean ecosystems as provincially and regionally notable. The porcupine dung habitat is exceptional and thus particularly important.

Underground habitats are in themselves unusual and fascinating, and cave ecosystems are natural systems that in most cases have not been directly modified by man. Also, due to the protection that they offer from large oscillations in climate, caves and subterranean waters 
are habitats where species normally living further to the north or to the south may sometimes be found (Gunn et al., 2000).

The cave fauna of Nova Scotia is now probably the most extensively and comprehensively sampled and documented of any geographic region in Canada. Records go back to the 1960s and large documented collections of both terrestrial and aquatic invertebrates have been made since then in caves and abandoned underground mines around the province.

Invasive and other species in Maritime caves may have high potential for investigating and testing biospeleological evolutionary theories with populations at a very early stage of active colonisation and adaptation to the subterranean environment.

\section{ACKNOWLEDGEMENTS}

Any prolonged wide-ranging study is impossible without the help and participation of many individuals, and it is unfortunately impossible to name them all here. I would especially like to express my gratitude to the many taxonomists who identified specimens: there is a list in Moseley (1998). Mention must also be made of those individuals who accompanied me on field trips: especially M. Hamilton, C. Murphy, the Proctor brothers, Dr. D. Sawatzky, and the late Dr. P. Schwinghamer. My colleagues amongst the permanent staff and Research Associates of the Nova Scotia Museum of Natural History have also helped in many ways. Dr. Dale Calder (Royal Ontario Museum) commented on the manuscript and also provided useful unpublished data from Frenchman's Cave. Additional unpublished records were generously provided by Dr. Don McAlpine (NB Museum) as well as by Calum Ewing and Andrew Hebda (NS Museum) who also prepared Fig. 1. A mention needs to be made of Harry Bassett and Fred St. Peters who skillfully recovered decades of notes and raw data from a set of corrupted computer diskettes. Finally, thank you to the two anonymous reviewers who critiqued the draft manuscript and made a number of very useful and constructive suggestions.

Fieldwork in 1996/97 was supported in part by a grant from the endowment fund of the Nova Scotia Museum Board of Governors. Fig. 1 was generated from the NS Museum MIMS database.

\section{REFERENCES}

Arsenault S. P., Schroeder J., Bérubé D. \& Albert R., 1997 - The caves of southeastern New Brunswick (Revised and Supplemented), Issue 97-7, Open Files, Minerals and Energy Division, Dept. of Natural Resources and Energy, New Brunswick, 33 p.

Banfield A.W., 1974 - The Mammals of Canada. National Museums of Canada, Univ. of Toronto Press, 438 p.

Bleakney J.S., 1965 - First Specimens of Eastern Pipistrelle from Nova Scotia. J. Mamm., 46: 528-529.

Bousfield E.L. \& Holsinger J. R., 1981 - A second new subterranean amphipod crustacean of the genus Stygobromus (Crangonyctidae) from Alberta, Canada. Canadian J. Zool., 59: 1827-1830.
Calder D. R. \& Bleakney J. S., 1965 - Microarthropod Ecology of a Porcupine-Inhabited Cave in Nova Scotia. Ecology, 46 (6): 895-899.

Calder D. R. \& Bleakney J. S., 1967 - Observations on Frenchman's Cave, Nova Scotia, and Its Fauna. Bull. Nat. Spel. Soc., 29 (1): 23-25.

Chapman P., 1993 - Caves and Cave Life, New Naturalist, Harper Collins, London, 219 p.

Christiansen K. \& Bellinger P., 1998 - The Collembola of North America North of the Rio Grande: A Taxonomic Analysis. Grinnell College, Grinnell, Iowa, 1520 p.

Christiansen K. \& Bellinger P., 1980 - The Collembola of North America North of the Rio Grande. Grinnell College, Grinnell, Iowa, $1322 \mathrm{p}$.

DeHarveng L. \& Bedos A., 2000 - The Cave Fauna of Southeast Asia. Origins, Evolution and Ecology. In: Wilkens H., Culver D. C. \& Humphreys W. F. (Eds.) - Ecosystems of the World: Vol. 30, Subterranean Biota. Elsevier, Amsterdam: 603-632.

Emerton J. H., 1917 - Spiders Collected in Nova Scotia and New Brunswick by Robt. Matheson in 1912. Proc. N. S. Ent. Soc., 1917: 95-96.

Gibert J. \& DeHarveng L., 2002 - Subterranean ecosystems: a truncated functional biodiversity. BioScience, 52: 473-481.

Gnaspini P., 1992 - Bat guano ecosystems. A new classification and some considerations, with special reference to Neotropical data. Mem. Biospéléol., 19: 135-138.

Gnaspini P. \& Trajano E., 2000 - Guano Communities in Tropical Caves. In: Wilkens H., Culver D. C. \& Humphreys W. F. (Eds.) - Ecosystems of the World: Vol. 30, Subterranean Biota. Elsevier, Amsterdam: 251268

Gould V. E., 1936 - Nova Scotia mammal notes. Can. Field-Nat., 50 (6): 103-104.

Graham R. E., 1962 - Porcupine cave dens in California. Cave Notes, Cave Research Associates, USA, 4 (1): 1-4.

Gunn J., Hardwick P. \& Wood P.J., 2000 - The Invertebrate Community of the Peak-Speedwell Cave System, Derbyshire, England - Pressures and Considerations for Conservation Management. Aq. Conserv., 10: 353-369.

Holsinger J. R. 1980 - Stygobromus canadensis, a new subterranean amphipod crustacean (Crangonyctidae) from Canada, with remarks on Wisconsin refugia. Can. J. Zool., 58(2): 90-97.

Howarth F., 1972 - Cavernicoles in Lava Tubes on the Island of Hawaii. Science, 175 (4019): 325-326.

Howarth F., 1988 - Environmental Ecology of North Queensland Caves. In: Pearson, L. (Ed.) - Preprints of papers for the 17th biennial conference, Australian Speleological Federation Tropicon Conference, Lake Tinaroo, Far North Queensland, December 27-31, 1988.

Jeannel R., 1926 - Faune cavernicole de la France, avec une étude des conditions d'existence dans le domaine souterraine. P. Lechevalier ed. Paris, $334 \mathrm{p}$.

Jefferson G. T., 1981 - Diptera in British Caves. In: Beck, B.F. (Ed.) - Proceedings of the 8th International Congress on Speleology, Bowling Green, Kentucky, Vol. 1: 106-107.

Juberthie C., 1984 - La colonisation du milieu souterrain: 
theories et methods, relations avec la speciation et l'évolution souterraine. Mem. Biospéléol., 11: 65-102.

Kane T. C. \& Culver D. C., 1992 - Biological Processes in Space and Time: Analysis of Adaptation. In: Camacho, A. I. (Ed.) - The Natural History of Biospeleology, Madrid, Monografias del Museo Nacional de Ciencias Naturales: 423-451.

King L.H., 1996 - Late Wisconsin ice retreat from the Scotian Shelf. Bull. Geol. Soc. Am., 108: 1056-1067.

Lee C. E., 2002 - Evolutionary genetics of invasive species. Trends Ecol. Evol., 17 (8): 386-391.

Majka C. J., Moseley M. \& Klimaszewski J., in press - Gennadota canadensis (Casey) (Staphylinidae: Aleocharinae): new records, a range extension, and bionomic notes. Coleop. Bull.

Marusik Y. M. \& Koponen S., 1992 - A Review of Meta (Araneae, Tetragnathidae) with Description of Two New Species. J. Arachnol., 20: 137-143.

McAlpine D. F., 1976 - First record of the Eastern Pipistrelle in New Brunswick. Can. Field-Nat., 90: 476.

McAlpine D. F., 1977 - Notes on Cave Utilization by Beaver. Bull. Nat. Speleo. Soc., 39 (3): 90-91.

McAlpine D. F., 1979 - Preliminary Investigations on the Solution Caves of New Brunswick. J. New Brunswick Mus., 1979: 99-107.

McAlpine D. F. \& Reynolds J. W., 1977 - Terrestrial Oligochaeta of Some New Brunswick Caves with Remarks on Their Ecology. Can. Field-Nat., 91: 360-366.

Moore K., 1963 - Hayes Cave: a study. Unpub. MS, N. S. Museum, Halifax, Canada, 21 p.

Morris L. (Ed.), 1985 - The Hayes Cave Site, South Maitland, Nova Scotia. Cur. Rep. 50, N. S. Museum, Halifax, Canada, 128 p.

Moseley M., 1975 - The Protection of Caves in Nova Scotia. Nova Scotia Speleo. Soc. Newsletter, 5: 1-23. N. S. Museum, Halifax, Canada.

Moseley M., 1976 - Caves of the Atlantic Region. In: Thompson, P (Ed.) - Cave Exploration in Canada. Canadian Caver, Univ. Alberta, Canada: 8-18.

Moseley M., 1996 - The gypsum karst and caves of the Canadian Maritimes. Cave and Karst Sci., 23 (1): 5-16.

Moseley M., 1998 - Invertebrate Fauna of Nova Scotia Caves. Cur. Rept. 86, N. S. Museum, Halifax, Canada, 37 p.

Moseley M., in press - Records of Bats (Chiroptera) at Caves and Mines in Nova Scotia. Cur. Rept., N. S.museum, Halifax, Canada.
Moseley M. \& Hebda A., 2001 - Overwintering Leiobunum elegans (Opiliones: Phalangiidae) in Caves and Mines in Nova Scotia. Proc. N. S. Inst. Sci., 41 (4): 216-218.

Moseley M., Klimaszewski J. \& Majka C. J., 2006 - Description of the pupa and observations on the distribution, ecology and life history of Quedius spelaeus spelaeus Horn (Coleoptera: Staphylinidae) in Nova Scotia, Canada. Zootaxa, 1226: 61-68.

Peck S. B., 1988 - A review of the cave fauna of Canada, and the composition and ecology of the invertebrate fauna of caves and mines in Ontario. Can. J. Zool., 66: $1197-1213$.

Sawatzky K., 1986 - Diving in Diogenes. Can. Caver, 18 (1): 16-20.

Schmidt R. E., 1986 - Zoogeography of the Northern Appalachians. In: Hocutt, C.H. \& E.O. Wiley (Eds.) - The Zoogeography of North American Freshwater Fishes. John Wiley \& Sons, NY: 137-159.

Schwert D. P., 1979 - Description and significance of a fossil earthworm (Oligochaeta: Lumbricidae) cocoon from postglacial sediments in southern Ontario. Can. J. Zool., 57 (7): 1402-1405.

Scott F. 1979 - Preliminary Investigations at Hayes Cave, Hants County, Nova Scotia in 1978. Cur. Rept. 38, N. S. Museum, Halifax, Canada, 14 p.

Scott F. \& Grantham R., 1985 - The Cave Environment. In: Morris, L (Ed.) - The Hayes Cave Site, South Maitland, Nova Scotia. Cur. Rept. 50, N. S. Museum, Halifax, Canada: 101-115.

Scott F. \& Hebda A. J., 2004 - Annotated List of the Mammals of Nova Scotia. Proc. N. S. Inst. Sci., 42 (2): 189-208.

Shaw P. \& Davis M., 2000 - Invertebrates from Caves on Vancouver Island In: Darling, L. M. (Ed.) - Proceedings of a Conference on the Biology and Management of Species and Habitats at Risk, Kamloops, B.C., 15-19 February, 1999, Vol. One. B.C. Ministry of Environment Lands and Parks, Victoria, B.C. and Univ. College of the Cariboo, Kamloops, B.C: 121-124.

Trevor-Deutsch B., 1973 - The role of hibernating bats in the winter diet of Peromyscus spp. (Rodentia: Cricetidae). Unpub. Ph.D. Thesis, Carleton Univ., Ottawa, Canada.

Wright B., 1979 - Mites, Ticks, Fleas and Lice in the Nova Scotia Museum and Acadia University Museum Collections. Proc. N. S. Inst. Sci., 29: 185-196. 
Table 1. Summary of records of invertebrates from caves and mines in Nova Scotia and southern New Brunswick. [Abbreviations: th. $=$ threshold, d.th. $=$ deep threshold, d.z. = dark zone, Aq.= aquatic, $\mathrm{Tr}$. = terrestrial, Am. = amphibian, $\mathrm{PR}=$ bat ectoparasite, $\mathrm{Ne}=\mathrm{Nearctic}, \mathrm{Cp}=$ cosmopolitan, $\mathrm{Cl}=$ circumpolar, $\mathrm{Ad}=$ non-indigenous Palaearctic introduction), $\mathrm{AC}=$ accidental (stray), $\mathrm{HT}=$ habitual trogloxene, $\mathrm{TP}=$ troglophile, $\mathrm{GP}=$ guanophile, $(\mathrm{P})=$ parietal fauna. For key to alphanumeric site codes, see text]. [References: ${ }^{\circ}=$ Calder \& Bleakney, $1965 ;{ }^{1}=$ Calder \& Bleakney, $1967 ;{ }^{2}$ McAlpine \& Reynolds, $1977 ;{ }^{3}=$ Scott, $1979 ;{ }^{a}=$ McAlpine, $1979 ;{ }^{*}=$ Moseley \& Hebda, 2001; ${ }^{* *}=$ Moseley et al., 2006; ${ }^{* * *}=$ Wright, $1979 ;^{\wedge}=$ McAlpine, pers. comm.]

\begin{tabular}{|c|c|c|c|c|c|c|c|c|c|c|c|c|c|}
\hline \multirow{3}{*}{$\begin{array}{l}\text { CLASS or } \\
\text { ORDER } \\
\text { Ciliata }\end{array}$} & \multirow[t]{2}{*}{ FAMILY } & \multirow[b]{2}{*}{ TAXON } & \multicolumn{4}{|c|}{ Habitat collected } & \multicolumn{4}{|c|}{ Seasons recorded } & \multirow[b]{2}{*}{ Sites } & \multirow{2}{*}{\multicolumn{2}{|c|}{$\begin{array}{l}\text { Distribution } \\
\text { \& ecology }\end{array}$}} \\
\hline & & & \multirow{2}{*}{$\begin{array}{l}\text { th. } \\
+\end{array}$} & \multirow{2}{*}{$\begin{array}{c}\text { d.th. } \\
+\end{array}$} & \multirow{2}{*}{$\begin{array}{c}\text { d.z. } \\
+\end{array}$} & \multirow{2}{*}{$\begin{array}{c}\begin{array}{c}\text { main } \\
\text { substrate(s) }\end{array} \\
\text { pools, etc. }\end{array}$} & \multirow[t]{2}{*}{ DJF } & \multirow[t]{2}{*}{ MAM } & \multirow[t]{2}{*}{ JJA } & \multirow[t]{2}{*}{ SON } & & & \\
\hline & \multicolumn{2}{|c|}{ Fam. \& spp. indet } & & & & & & & & & & $\mathrm{Ag}$ & $?$ \\
\hline \multirow[t]{2}{*}{ Turbellaria } & \multirow[t]{2}{*}{ Planaridae } & Sp. A indet. & & & + & pools & & & + & + & $\begin{array}{c}\mathrm{CB}, \mathrm{PT}, \mathrm{GM} \text {, } \\
\mathrm{KC}\end{array}$ & $\mathrm{Aq}$ & $?$ \\
\hline & & Sp. B indet. & & & + & pools & & & + & + & $\mathrm{KC}$ & $\mathrm{Aq}$ & $?$ \\
\hline \multirow[t]{7}{*}{ Oligochaeta } & \multirow[t]{4}{*}{ Lumbricidae } & $\begin{array}{c}\text { Dendrodrilus rubidus } \\
\text { (Savigny) }\end{array}$ & + & + & + & $\begin{array}{l}\text { various } \\
\text { organic }\end{array}$ & + & & + & + & & $\mathrm{Tr}, \mathrm{Cp}$ & $\mathrm{HT}$ \\
\hline & & $\begin{array}{c}\text { Aporrectodea } \\
\text { tuberculata (Eisen) }\end{array}$ & + & + & + & $\begin{array}{l}\text { various } \\
\text { organic }\end{array}$ & & + & + & + & & $\mathrm{Tr}, \mathrm{Ad}$ & $\mathrm{HT}$ \\
\hline & & $\begin{array}{c}\text { Lumbricus terrestris } \\
\text { L. }\end{array}$ & & + & + & $\begin{array}{l}\text { various } \\
\text { organic }\end{array}$ & & & + & + & $\begin{array}{l}\mathrm{CB}, \mathrm{GM}^{2} \\
\mathrm{GP}^{2}\end{array}$ & $\mathrm{Tr}, \mathrm{Ad}$ & HT \\
\hline & & $\begin{array}{l}\text { Eisenia rosea } \\
\text { (Savigny) }\end{array}$ & + & + & + & cave soil & & & + & + & $\mathrm{PT}, \mathrm{HO}^{2}$ & $\mathrm{Tr}, \mathrm{Ad}$ & HT \\
\hline & \multirow[t]{2}{*}{ Enchytraeidae } & Spp. indet & + & + & + & $\begin{array}{l}\text { various } \\
\text { organic }\end{array}$ & + & + & + & + & All/most & $\operatorname{Tr}$ & GP \\
\hline & & Spp. indet. & + & + & + & pools, etc. & + & + & + & + & All/most & $\mathrm{Aq}$ & TP \\
\hline & Naiidae & Spp. indet. & & & + & pools, etc. & + & + & + & + & $\mathrm{FC}$ & $\mathrm{Aq}$ & TP \\
\hline Hirudina & Glossiphonidae & $\begin{array}{l}\text { Helobdella papillata } \\
\text { (Moore) }\end{array}$ & & & + & pool & & & + & & BB & $\mathrm{Aq}, \mathrm{Ne}$ & $A C$ \\
\hline \multirow[t]{2}{*}{ Cladocera } & \multirow[t]{2}{*}{ Fam indet. } & Sp. A indet. & & & + & pool & & & + & & $\mathrm{CB}$ & $\mathrm{Aq}$ & $\mathrm{AC}$ \\
\hline & & Sp. B indet. & & & + & pool & & & + & & CB & $\mathrm{Aq}$ & $A C$ \\
\hline \multirow[t]{5}{*}{ Ostracoda } & \multirow[t]{2}{*}{ Candonidae } & $\begin{array}{l}\text { Pseudocandona } \\
\text { albicans (Brady) }\end{array}$ & & + & + & stream, pool & & & + & + & WB,CC & $\mathrm{Aq}$ & TP \\
\hline & & $\begin{array}{l}\text { Fabaeformiscandona } \\
\text { wegelini (Petkovsky) }\end{array}$ & & & + & pool & & & & + & $\mathrm{CC}$ & $\mathrm{Aq}, \mathrm{Cp}$ & TP \\
\hline & \multirow[t]{2}{*}{ Cypridae } & Cypria sp. & & + & & stream & & & + & & WB & $\mathrm{Aq}$ & HT \\
\hline & & Cavernocypris sp. & & + & & stream & & & + & & WB & $\mathrm{Aq}$ & TP \\
\hline & Cypridopsidae & Cypridopsis sp. & & + & & stream & & & + & & WB & $\mathrm{Aq}$ & HT \\
\hline \multirow[t]{8}{*}{ Copepoda } & Cyclopoidae & $\begin{array}{l}\text { Acanthocyclops } \\
\text { robustus (Sars) }\end{array}$ & & + & & pool, sediment & & & + & + & CB & $\mathrm{Aq}, \mathrm{Cp}$ & TP \\
\hline & & $\begin{array}{c}\text { A. brevispinosus } \\
\text { (Herrick) }\end{array}$ & & + & & stream & & & + & & WB & $\mathrm{Aq}, \mathrm{Ne}$ & TP \\
\hline & & A. venustoides Coker & + & & & pool with dung & & + & & & PT & $\mathrm{Aq}, \mathrm{Ne}$ & $A C$ \\
\hline & & $\begin{array}{l}\text { Eucyclops agilis } \\
\text { (Koch) }\end{array}$ & & & + & pool & & & + & & CB & $\mathrm{Aq}, \mathrm{Cp}$ & TP \\
\hline & & $\begin{array}{c}\text { Diacyclops } \\
\text { brachycerus (Kiefer) }\end{array}$ & & + & & stream & & & + & + & WIC,WB & $\mathrm{Aq}, \mathrm{Cp}$ & TP \\
\hline & & $\begin{array}{l}\text { Paracyclops poppei } \\
\text { (Rehberg) }\end{array}$ & & & + & pool & & & + & & CB & $\mathrm{Aq}, \mathrm{Cp}$ & $A C$ \\
\hline & & $\begin{array}{c}\text { Macrocyclops albidus } \\
\text { (Jurine) }\end{array}$ & & & + & sediment & & & & + & CB & $\mathrm{Aq}, \mathrm{Cp}$ & TP \\
\hline & & Sp. indet. & & + & & sediment & & & + & & WB & $\mathrm{Aq}$ & $?$ \\
\hline Isopoda & Oniscidae & Oniscus asellus (L.) & + & + & + & $\begin{array}{l}\text { cave wall, } \\
\text { dung }\end{array}$ & & + & + & + & & $\mathrm{Tr}, \mathrm{Ad}$ & $\operatorname{tTP}(\mathrm{P})$ \\
\hline Pauropoda & Fam. indet. & Sp. indet. & & & & no date & & & & & $\mathrm{FC}^{1}$ & Tr, & $?$ \\
\hline
\end{tabular}




\begin{tabular}{|c|c|c|c|c|c|c|c|c|c|c|c|c|c|}
\hline Chilopoda & Henicopidae & $\begin{array}{c}\text { Lamyctes fulvicornis } \\
\text { Meinert }\end{array}$ & & + & & $\begin{array}{l}\text { porcupine } \\
\text { dung }\end{array}$ & & & + & & FC & $\operatorname{Tr}, \mathrm{Ad}$ & $A C$ \\
\hline \multirow[t]{4}{*}{ Diplopoda } & Blaniulidae & $\begin{array}{l}\text { Proteroiulus fuscus } \\
\text { (Am Stein) }\end{array}$ & + & + & & $\begin{array}{l}\text { porcupine } \\
\text { dung }\end{array}$ & & & + & + & $\mathrm{FC}^{1}$ & $\operatorname{Tr}, \mathrm{Ad}$ & HT \\
\hline & \multirow[t]{2}{*}{ Julidae } & $\begin{array}{l}\text { Ophyiulus pilosus } \\
\text { (Newport) }\end{array}$ & & + & + & $\begin{array}{l}\text { porcupine } \\
\text { dung }\end{array}$ & & & + & + & $\mathrm{FC}^{1}$ & $\operatorname{Tr}, \mathrm{Ad}$ & HT \\
\hline & & $\begin{array}{l}\text { Allajulus latestriatus } \\
\text { (Curtis) }\end{array}$ & + & + & + & various & & & + & + & $\mathrm{FC}^{1}, \mathrm{~F} 2$ & $\operatorname{Tr}, \mathrm{Ad}$ & HT \\
\hline & Polydesmidae & $\begin{array}{c}\text { Polydesmus angustus } \\
\text { Latzel }\end{array}$ & + & + & & $\begin{array}{l}\text { porcupine } \\
\text { dung }\end{array}$ & & & + & + & FC & $\operatorname{Tr}, \mathrm{Ad}$ & $\mathrm{HT}(\mathrm{P})$ \\
\hline \multirow[t]{2}{*}{ Symphyla } & & Symphylella sp. & & & + & cave soil & & & + & & MB & $\operatorname{Tr}$ & TP \\
\hline & Scutigerellida & Scutigerella sp. & & & + & on pool & & & + & & KC & $\mathrm{Tr}$ & TP \\
\hline \multirow[t]{25}{*}{ Collembola } & \multirow[t]{4}{*}{ Poduridae } & $\begin{array}{l}\text { Hypogastrura } \\
\text { pseudarmata }\end{array}$ & & & + & timber & & & & + & $\mathrm{KC}$ & $\mathrm{Tr}, \mathrm{Ne}$ & TP \\
\hline & & $\begin{array}{l}\text { Neanura muscorum } \\
\text { (Tempelton) }\end{array}$ & & & + & timber & & & & + & KC & $\operatorname{Tr}, \mathrm{Ad}$ & TP \\
\hline & & Friesea sp. & & & + & $\begin{array}{l}\text { porcupine } \\
\text { dung }\end{array}$ & & & + & & GM & $\operatorname{Tr}, ?$ & $A C$ \\
\hline & & $\begin{array}{c}\text { Willemia scandinavia } \\
\text { Stach }\end{array}$ & + & + & & porcupine & & & + & & WIC & $\mathrm{Tr}, \mathrm{Cp}$ & HT \\
\hline & \multirow[t]{5}{*}{ Onychiuridae } & $\begin{array}{l}\text { Protaphorura } \\
\text { pseudarmatus }\end{array}$ & + & + & + & porcupine & & + & + & & $\mathrm{HC}, \mathrm{WIC}, \mathrm{FC}$ & $\mathrm{Tr}, \mathrm{Ne}$ & TP \\
\hline & & P. armata (Tullberg) & + & + & + & $\begin{array}{l}\text { porcupine } \\
\text { dung }\end{array}$ & + & + & + & + & $\begin{array}{l}\mathrm{HC}, \mathrm{FC}^{\circ} \\
\mathrm{F} 2, \mathrm{GM}\end{array}$ & $\mathrm{Tr}, \mathrm{Cp}$ & TP \\
\hline & & $\begin{array}{l}\text { P. cf. boedvarssoni } \\
\text { Pomorski }\end{array}$ & & & + & on pools & & + & & + & $\mathrm{CC}$ & $\operatorname{Tr}, ?$ & $?$ \\
\hline & & $\begin{array}{l}\text { Tullbergia iowensis } \\
\text { Mills }\end{array}$ & + & + & & $\begin{array}{l}\text { porcupine } \\
\text { dung }\end{array}$ & + & + & + & + & $\mathrm{FC}^{\circ}$ & $\mathrm{Tr}, \mathrm{Ne}$ & TP \\
\hline & & $\begin{array}{l}\text { T. roseki Christiansen } \\
\text { and Bellinger }\end{array}$ & & & + & $\begin{array}{l}\text { porcupine } \\
\text { dung }\end{array}$ & & & + & & $\mathrm{HC}$ & $\mathrm{Tr}, \mathrm{Ne}$ & HT \\
\hline & \multirow[t]{6}{*}{ Isotomidae } & Folsomia fimitaria (L.) & + & + & & $\begin{array}{l}\text { porcupine } \\
\text { dung }\end{array}$ & + & + & + & + & $\mathrm{FC}^{\circ}$ & $\operatorname{Tr}, \mathrm{Ad}$ & $\mathrm{TP}$ \\
\hline & & $\begin{array}{l}\text { F. stella Christiansen } \\
\text { \& Tucker }\end{array}$ & + & + & + & $\begin{array}{l}\text { porcupine } \\
\text { dung }\end{array}$ & & + & + & & $\mathrm{HC}, \mathrm{WIC}, \mathrm{FC}$ & $\mathrm{Tr}, \mathrm{Ne}$ & TP \\
\hline & & F. candida (Willem) & + & + & & $\begin{array}{l}\text { dung, pool } \\
\text { surface }\end{array}$ & + & + & & + & MIC, wells & $\mathrm{Tr}, \mathrm{Ne}$ & TP \\
\hline & & $\begin{array}{l}\text { Isotoma notabilis } \\
\text { Schäffer }\end{array}$ & \multicolumn{8}{|c|}{ no data } & $\mathrm{FC}^{\circ}$ & $\mathrm{Tr}, \mathrm{Ne}$ & HT \\
\hline & & I. caeruleatra Guthrie & & & + & plant litter & & & + & & $\mathrm{CB}$ & $\mathrm{Tr}, \mathrm{Ne}$ & $A C$ \\
\hline & & Isotoma sp. nova? & & + & + & $\begin{array}{l}\text { various } \\
\text { organic }\end{array}$ & & + & + & + & $\mathrm{HC}, \mathrm{FC}$ & $\operatorname{Tr}$ & TP \\
\hline & \multirow[t]{5}{*}{ Entomobryidae } & $\begin{array}{l}\text { Heteromurus nitidus } \\
\text { (Templeton) }\end{array}$ & + & + & + & oligotrophic & & + & + & + & & $\operatorname{Tr}, \mathrm{Ad}$ & $\mathrm{TP}$ \\
\hline & & $\begin{array}{l}\text { Pseudosinella alba } \\
\text { (Packard) }\end{array}$ & + & + & + & on pools, dung & & & & + & $\mathrm{HC}, \mathrm{FC}^{\circ}$ & $\mathrm{Tr}, \mathrm{Ne}$ & $\mathrm{TP}$ \\
\hline & & P. collina Wray & & & + & timber & & & & + & $\mathrm{KC}$ & $\mathrm{Tr}, \mathrm{Ne}$ & TP \\
\hline & & $\begin{array}{c}\text { Entomobrya nivalis } \\
\text { (L.) }\end{array}$ & + & & & \multicolumn{5}{|c|}{ no data } & $\mathrm{FC}^{\circ}$ & $\mathrm{Tr}, \mathrm{Cp}$ & $A C$ \\
\hline & & $\begin{array}{l}\text { Tomoceros minor } \\
\text { (Lubbock) }\end{array}$ & & & + & $\begin{array}{l}\text { porcupine } \\
\text { dung }\end{array}$ & & & + & & $\mathrm{CB}$ & $\operatorname{Tr}, \mathrm{Ad}$ & $\mathrm{TP}$ \\
\hline & Neelidae & $\begin{array}{l}\text { Megalothorax } \\
\text { minimus Willem }\end{array}$ & + & + & & $\begin{array}{l}\text { porcupine } \\
\text { dung }\end{array}$ & + & + & + & + & $\mathrm{FC}^{\circ}$ & $\mathrm{Tr}, \mathrm{Ne}$ & GP \\
\hline & \multirow[t]{4}{*}{ Sminthuridae } & $\begin{array}{c}\text { Arrhopalites } n r . \\
\text { pygmaeus (Wankel) }\end{array}$ & & + & & oligotrophic & & & & + & $\mathrm{F} 2$ & $\operatorname{Tr}$ & HT \\
\hline & & A. hirtus Christiansen & & + & + & $\begin{array}{l}\text { oligotrophic \& } \\
\text { on pools }\end{array}$ & & & & + & F2 & $\mathrm{Tr}, \mathrm{Ne}$ & $\mathrm{TP}$ \\
\hline & & $\begin{array}{c}\text { Sminthurides } \\
\text { malmgreni (Tullberg) }\end{array}$ & & & + & wet plant litter & & & & + & $\mathrm{F} 2$ & $\mathrm{Tr}, \mathrm{Cp}$ & $A C$ \\
\hline & & $\begin{array}{c}\text { Ptenothrix marmorata } \\
\text { (Packard) }\end{array}$ & + & + & + & $\begin{array}{l}\text { timber; on } \\
\text { pool }\end{array}$ & & & + & + & $\mathrm{CB}, \mathrm{FC}^{\circ}, \mathrm{KC}$ & $\mathrm{Tr}, \mathrm{Ne}$ & $\mathrm{HT}$ \\
\hline
\end{tabular}




\begin{tabular}{|c|c|c|c|c|c|c|c|c|c|c|c|c|c|}
\hline Ephemeroptera & \multicolumn{2}{|c|}{ Fam. et sp. indet (nymphs) } & & & + & stream & & + & & & $\mathrm{HB}^{\wedge}$ & $\mathrm{Ada}$ & $?$ \\
\hline \multirow[t]{4}{*}{ Odonata } & \multirow[t]{2}{*}{ Aeshnidae } & $\begin{array}{l}\text { Aeshna umbrosa } \\
\text { Walker nymphs }\end{array}$ & & + & & pools & & & & + & $\mathrm{HC}$ & $\mathrm{Aq}, \mathrm{Ne}$ & $\mathrm{HT}$ \\
\hline & & $\begin{array}{l}\text { Aeshna sp. indet. } \\
\text { nymphs }\end{array}$ & + & + & & pools & & & + & & $\mathrm{HC}$ & $\mathrm{Aq}, \mathrm{Ne}$ & $\mathrm{HT}$ \\
\hline & & $\begin{array}{l}\text { Cordulegaster } \\
\text { maculata Selys }\end{array}$ & & + & & stream & & & & + & CB & $\mathrm{Aq}, \mathrm{Ne}$ & $A C$ \\
\hline & Macromidae & $\begin{array}{l}\text { Macromia illinoiensis } \\
\text { Walsh nymphs }\end{array}$ & + & + & & pools & & & + & & $\mathrm{HC}$ & $\mathrm{Aq}, \mathrm{Ne}$ & HT \\
\hline \multirow[t]{6}{*}{ Plecoptera } & Capnidae & Sp. indet. nymphs & & + & & stream & & & + & & WB & $\mathrm{Aq}$ & $\mathrm{AC}$ \\
\hline & Leuctridae & Sp. indet. adults & + & + & + & cave walls & & & + & & WB, KC & $\mathrm{Aq}$ & HT \\
\hline & Nemouridae & $\begin{array}{l}\text { Amphinemura sp. } \\
\text { nymphs }\end{array}$ & & + & & stream & & + & & & WB & $\mathrm{Aq}$ & $A C$ \\
\hline & & $\begin{array}{l}\text { Taeniopteryx sp. } \\
\text { nymphs }\end{array}$ & + & + & & $\begin{array}{l}\text { seeps \& wet } \\
\text { plant litter }\end{array}$ & & & & + & $\mathrm{FC}, \mathrm{F} 2$ & $\mathrm{Aq}$ & $\mathrm{AC}$ \\
\hline & Chloroperlidae & $\begin{array}{l}\text { Haploperla sp. } \\
\text { nymphs }\end{array}$ & + & + & + & stream & & + & + & & $\mathrm{F} 2$ & $\mathrm{Aq}$ & $\mathrm{HT}$ \\
\hline & Perlidae & Sp. indet. nymphs & & & + & stream & & & + & & $\mathrm{KC}$ & $\mathrm{Aq}$ & $\mathrm{HT}$ \\
\hline \multirow[t]{2}{*}{ Orthoptera } & & $\begin{array}{c}\text { Ceuthophilus brevipes } \\
\text { (Scudder) }\end{array}$ & + & + & & cave wall & + & + & & + & TH,PT & $\mathrm{Tr}, \mathrm{Ne}$ & $\mathrm{HT}(\mathrm{P})$ \\
\hline & & C. maculatus (Harris) & + & & & $\begin{array}{c}\text { bait } \\
\text { (molasses) }\end{array}$ & & & + & & WIC & $\mathrm{Tr}, \mathrm{Ne}$ & $\mathrm{AC}$ \\
\hline \multirow[t]{14}{*}{ Coleoptera } & \multirow[t]{3}{*}{ Dytiscidae } & $\begin{array}{c}\text { Agabus semivittatus } \\
\text { (Le Conte) }\end{array}$ & & & + & stream & & & & & CB & $\mathrm{Aq}, \mathrm{Ne}$ & $\mathrm{AC}$ \\
\hline & & $\begin{array}{c}\text { A. larsoni Ferry \& } \\
\text { Nilsson }\end{array}$ & + & + & + & stream, pool & & & + & & $\mathrm{HC}, \mathrm{DC}$ & $\mathrm{Aq}, \mathrm{Ne}$ & HT \\
\hline & & $\begin{array}{l}\text { Dytiscus sp. indet. } \\
\text { larva }\end{array}$ & & & + & stream & & & + & & CB & $\mathrm{Aq}, ?$ & $\mathrm{AC}$ \\
\hline & Hydrophilidae & $\begin{array}{l}\text { Crenitis digesta } \\
\text { (LeConte). }\end{array}$ & + & & & cave wall & & & & + & $\mathrm{F} 2$ & $\operatorname{Tr}, \mathrm{Ad}$ & $A C$ \\
\hline & \multirow[t]{5}{*}{ Staphylinidae } & $\begin{array}{c}\text { Quedius s. spelaeus } \\
\text { Horn larvae and }\end{array}$ & + & + & + & $\begin{array}{l}\text { porcupine } \\
\text { dung }\end{array}$ & + & + & + & + & & $\mathrm{Tr}, \mathrm{Ne}$ & TP \\
\hline & & $\begin{array}{l}\text { Q. mesomelinus } \\
\text { (Marsham) }\end{array}$ & & & + & plant litter & & & & + & $\mathrm{KC}$ & $\operatorname{Tr}, \mathrm{Ad}$ & TP \\
\hline & & $\begin{array}{l}\text { Brathinus nitidus } \\
\text { LeConte }\end{array}$ & & & + & $\begin{array}{l}\text { various } \\
\text { organic }\end{array}$ & & & & + & $\mathrm{FC}^{1}, \mathrm{FH} 2$ & $\operatorname{Tr}, \mathrm{Ad}$ & TP \\
\hline & & $\begin{array}{c}\text { Gennadota } \\
\text { canadensis Casey }\end{array}$ & + & & & $\begin{array}{c}\text { bait } \\
\text { (molasses) }\end{array}$ & & + & & & WIC & $\mathrm{Tr}, \mathrm{Ne}$ & TP \\
\hline & & Atheta sp. indet. & & + & & cave wall & & & + & & PT & $\mathrm{Tr}, \mathrm{Ne}$ & $?$ \\
\hline & Curculionidae & $\begin{array}{l}\text { Sciaphus asperatus } \\
\text { (Bonsdoff) }\end{array}$ & & + & & $\begin{array}{c}\text { bait } \\
\text { (molasses) }\end{array}$ & & & & + & $\mathrm{F} 2$ & $\operatorname{Tr}, \mathrm{Ad}$ & $A C$ \\
\hline & Dermestidae & $\begin{array}{c}\text { Dermestus lardarius } \\
\text { L. }\end{array}$ & & + & & cave wall & & & & + & $\mathrm{F} 2$ & $\mathrm{Tr}, \mathrm{Cp}$ & $A C$ \\
\hline & Scarabaeidae & $\begin{array}{c}\text { Aphodius leopardus } \\
\text { Horn }\end{array}$ & & + & & $\begin{array}{l}\text { porcupine } \\
\text { dung }\end{array}$ & & & & + & $\mathrm{FC}^{1}$ & $\mathrm{Tr}, \mathrm{Ne}$ & GP \\
\hline & Latridae & $\begin{array}{l}\text { Corticaria serrata } \\
\text { (Paykull) }\end{array}$ & & + & & $\begin{array}{l}\text { porcupine } \\
\text { dung }\end{array}$ & & & & + & MIC & $\mathrm{Tr}, \mathrm{Ad}$ & GP \\
\hline & Ptilidae & $\begin{array}{c}\text { Acrotrichis castanea } \\
\text { (Matthews) }\end{array}$ & & + & + & $\begin{array}{l}\text { porcupine } \\
\text { dung }\end{array}$ & + & + & + & + & $\mathrm{F} 2$ & $\mathrm{Tr}, \mathrm{Ne}$ & GP \\
\hline Trichoptera & Limnephilidae & Sp. indet. adult & + & & & cave wall & & & + & & $\mathrm{DC}, \mathrm{HB}^{\wedge}$ & $\mathrm{Tr}, ?$ & $\mathrm{HT}(\mathrm{P})$ \\
\hline \multirow[t]{4}{*}{ Lepidoptera } & Acrophilidae & $\begin{array}{l}\text { Amydria effrentella } \\
\text { Clem }\end{array}$ & + & & & cave wall & & & + & & PT & $\mathrm{Tr}, \mathrm{Ne}$ & $A C$ \\
\hline & \multirow[t]{2}{*}{ Geometridae } & $\begin{array}{l}\text { Triphosa haesitata } \\
\text { affirmaria (Walker) }\end{array}$ & & & & cave wall & & & & & & $\mathrm{Tr}, \mathrm{Ne}$ & $\mathrm{HT}(\mathrm{P})$ \\
\hline & & $\begin{array}{l}\text { Xanthotype sospeta } \\
\text { (Drury) }\end{array}$ & + & & & cave wall & & & + & & $\mathrm{FC}$ & $\mathrm{Tr}, \mathrm{Ne}$ & $A C$ \\
\hline & Noctuidae & $\begin{array}{c}\text { Scoliopteryx libatrix } \\
\text { L. }\end{array}$ & + & + & & cave wall & & + & & + & GP,GR,HO & $\mathrm{Tr}, \mathrm{Cl}$ & $\mathrm{HT}(\mathrm{P})$ \\
\hline
\end{tabular}




\begin{tabular}{|c|c|c|c|c|c|c|c|c|c|c|c|c|c|}
\hline \multirow[t]{34}{*}{$\begin{array}{l}\text { Diptera: } \\
\text { Nematocera }\end{array}$} & \multirow[t]{5}{*}{ Tipulidae } & $\begin{array}{l}\text { Limonia cinctipes Say } \\
\text { adult }\end{array}$ & + & & & cave wall & & & + & & WB & \multirow{2}{*}{$\mathrm{Tr}, \mathrm{Cl}$} & \multirow{2}{*}{$\mathrm{TP}(\mathrm{P})$} \\
\hline & & - ditto -- larva & & + & + & $\begin{array}{l}\text { porcupine } \\
\text { dung }\end{array}$ & & & + & + & WIC, FC, F2 & & \\
\hline & & $\begin{array}{l}\text { Dolichopeza sp. } \\
\text { sensu lato }\end{array}$ & + & & & cave wall & & & + & & $\mathrm{KC}$ & $\mathrm{Tr}, ?$ & $\mathrm{HT}(\mathrm{P})$ \\
\hline & & Tipula sp. larva & & & + & veg. litter & & + & & & $\mathrm{F} 2$ & $\mathrm{Tr}, ?$ & $A C$ \\
\hline & & $\begin{array}{l}\text { Erioptera pilipes } \\
\text { (Fabricius) larva }\end{array}$ & & & + & veg. litter & & & & + & $\mathrm{CB}$ & $\mathrm{Tr}, \mathrm{Ne}$ & $\mathrm{AC}$ \\
\hline & \multirow[t]{3}{*}{ Trichoceridae } & Trichocera sp. indet & & + & & $\begin{array}{l}\text { porcupine } \\
\text { dung }\end{array}$ & & & & + & WIC & $\mathrm{Tr}, ?$ & $\operatorname{TP}(\mathrm{P})$ \\
\hline & & $\begin{array}{l}\text { T. maculipennis } \\
\text { Meigen adult }\end{array}$ & + & + & + & cave wall & & + & + & + & most sites & \multirow{2}{*}{$\operatorname{Tr}, \mathrm{Cp}$} & \multirow{2}{*}{$\mathrm{TP}(\mathrm{P})$} \\
\hline & & - ditto -- larva & & + & + & $\begin{array}{l}\text { porcupine } \\
\text { dung }\end{array}$ & & & + & + & most sites & & \\
\hline & \multirow[t]{4}{*}{ Culicidae } & Culex pipiens L. 우 & + & + & + & cave wall & + & & & + & $\mathrm{CC}, \mathrm{MC}$ & $\operatorname{Tr}, \mathrm{Cp}$ & $\mathrm{HT}(\mathrm{P})$ \\
\hline & & $\begin{array}{c}\text { C. restuans Theobald } \\
\text { o }\end{array}$ & & & & cave wall & + & & & + & & $\operatorname{Tr}, \mathrm{Ne}$ & $\mathrm{HT}(\mathrm{P})$ \\
\hline & & C. territans Walker $q$ & & & & cave wall & + & & & + & & $\operatorname{Tr}, \mathrm{Cp}$ & $H T(P)$ \\
\hline & & Anopheles sp. ${ }^{\lambda}$ & + & & & cave wall & & & + & & WB & $\operatorname{Tr}$ & $H T(P)$ \\
\hline & Chaoboridae & Chaoborus sp. & + & + & & various & & & + & + & F2, WB & $\operatorname{Tr}$ & $\mathrm{HT}(\mathrm{P})$ \\
\hline & \multirow[t]{3}{*}{ Chironomidae } & Smittia sp. adult, larva & & + & + & $\begin{array}{l}\text { porcupine } \\
\text { dung }\end{array}$ & & & + & & $\mathrm{FC}^{1}, \mathrm{~F} 2$ & $\operatorname{Tr}$ & TP \\
\hline & & $\begin{array}{l}\text { Gen. et spp. indet } \\
\text { - adults }\end{array}$ & & + & + & $\begin{array}{l}\text { various } \\
\text { organic }\end{array}$ & & & & + & $\mathrm{FC}, \mathrm{F} 2$ & $\operatorname{Tr}$ & $?$ \\
\hline & & $\begin{array}{l}\text { Gen. et spp. indet } \\
\text {-larvae }\end{array}$ & & + & + & stream & & + & + & & $\mathrm{F} 2, \mathrm{WB}, \mathrm{KC}$ & $\mathrm{Aq}$ & $?$ \\
\hline & \multirow[t]{6}{*}{ Mycetophilidae } & Boletina sp. & + & + & & cave wall & & & & & FC & $\operatorname{Tr}$ & $H T(P)$ \\
\hline & & Bolitophilia sp. & + & + & + & cave wall & & & + & & $\mathrm{FC}, \mathrm{KC}$ & $\operatorname{Tr}$ & $H T(P)$ \\
\hline & & Rymosia sp. & + & + & + & cave wall & & & + & & GM & $\operatorname{Tr}$ & $H T(P)$ \\
\hline & & Exechia sp. & + & + & + & cave wall & & + & & + & $\begin{array}{c}\mathrm{HC}, \mathrm{CC}, \mathrm{PT} \\
\mathrm{MC}\end{array}$ & $\operatorname{Tr}$ & $\mathrm{HT}(\mathrm{P})$ \\
\hline & & Exechiopsis sp. & & + & + & cave wall & & + & & + & $\mathrm{CC}, \mathrm{PT}$ & $\operatorname{Tr}$ & $\mathrm{HT}(\mathrm{P})$ \\
\hline & & $\begin{array}{l}\text { Tarnania tarnania } \\
\text { (Dziedzieki) }\end{array}$ & + & + & & cave wall & & & + & & PT & $\mathrm{Tr}, \mathrm{Cl}$ & $H T(P)$ \\
\hline & \multirow[t]{7}{*}{ Sciaridae } & Bradysia sp. adult & & + & + & $\begin{array}{l}\text { porcupine } \\
\text { dung }\end{array}$ & & & & + & $\mathrm{FC}^{1}$ & $\operatorname{Tr}$ & GP \\
\hline & & Lycoriella sp. adult & & + & + & $\begin{array}{l}\text { porcupine } \\
\text { dung }\end{array}$ & & & + & & $\mathrm{CB}, \mathrm{FC}$ & $\operatorname{Tr}$ & GP \\
\hline & & Scatopsciara sp. adult & & + & + & $\begin{array}{l}\text { porcupine } \\
\text { dung }\end{array}$ & & & + & & $\mathrm{CB}, \mathrm{FC}$ & $\operatorname{Tr}$ & GP \\
\hline & & Unidentified adults & + & + & + & $\begin{array}{l}\text { dung, walls, } \\
\text { litter }\end{array}$ & & & + & + & most sites & \multirow{4}{*}{\multicolumn{2}{|c|}{$\begin{array}{c}(P)-\text { see } \\
\text { identified adults }\end{array}$}} \\
\hline & & Larva - type A & + & + & + & $\begin{array}{l}\text { porcupine } \\
\text { dung }\end{array}$ & & + & + & + & & & \\
\hline & & Larva - type B & & + & + & $\begin{array}{l}\text { porcupine } \\
\text { dung }\end{array}$ & & & + & + & $\mathrm{HC}$, WIC, CC & & \\
\hline & & Larva - type C & & & + & $\begin{array}{l}\text { porcupine } \\
\text { dung }\end{array}$ & & & & + & $\mathrm{F} 2$ & & \\
\hline & \multirow[t]{2}{*}{ Cecidomyidae } & Peromyia sp. & & & + & cave wall & & & + & & $\mathrm{KC}$ & $\operatorname{Tr}$ & $\mathrm{HT}(\mathrm{P})$ \\
\hline & & Gen. et sp. indet. & + & & & cave wall & & & + & & YRT & $\operatorname{Tr}$ & $?$ \\
\hline & Simulidae & Simulium sp. larva & & & + & stream gravel & & + & & & F2 & $\mathrm{Aq}$ & HT \\
\hline & \multirow[t]{2}{*}{ Psychodidae } & Psychoda sp. adult & & + & + & dung, wall & & & + & + & $\mathrm{F} 2$ & \multirow{2}{*}{$\operatorname{Tr}$} & \multirow{2}{*}{$\mathrm{HT}(\mathrm{P})$} \\
\hline & & -- ditto --- larva & & & + & veg. litter & & + & & & $\mathrm{F} 2$ & & \\
\hline
\end{tabular}




\begin{tabular}{|c|c|c|c|c|c|c|c|c|c|c|c|c|}
\hline \multirow[t]{8}{*}{$\begin{array}{c}\text { Diptera: } \\
\text { Brachycera }\end{array}$} & Tabanidae & Chrysops sp. larva & & & + & veg. litter & & + & & CB & $\operatorname{Tr}$ & $A C$ \\
\hline & Phoridae & $\begin{array}{c}\text { Megaselia } \\
\text { meconicera (Specier) }\end{array}$ & \multicolumn{7}{|c|}{ no data } & $\mathrm{FC}^{1}$ & Tr, ?? & TP \\
\hline & \multirow[t]{5}{*}{ Helomyzidae } & $\begin{array}{c}\text { Scoliocentra fraterna } \\
\text { Loew }\end{array}$ & \multicolumn{7}{|c|}{ no data } & $\mathrm{FC}^{1}$ & $\mathrm{Tr}, \mathrm{Ne}$ & $\mathrm{HT}(\mathrm{P})$ \\
\hline & & Helomyza serrata (L.) & & + & + & cave wall & & + & + & $\mathrm{FC}, \mathrm{CC}, \mathrm{PT}$ & $\mathrm{Tr}, \mathrm{Cl}$ & $\mathrm{HT}(\mathrm{P})$ \\
\hline & & $\begin{array}{l}\text { H. brachypterna } \\
\text { (Loew)? }\end{array}$ & & + & & cave wall & & + & & PT & $\mathrm{Tr}, \mathrm{Ne}$ & $\mathrm{HT}(\mathrm{P})$ \\
\hline & & Amoebaleria sp. & & + & + & cave wall & & + & + & $\mathrm{CC}, \mathrm{PT}$ & $\operatorname{Tr}$ & $\mathrm{HT}(\mathrm{P})$ \\
\hline & & Tephrachlamys sp. & & & + & cave wall & & & + & $\mathrm{F} 2$ & $\operatorname{Tr}$ & $\mathrm{HT}(\mathrm{P})$ \\
\hline & & $\begin{array}{c}\text { Leptocera (Limosina) } \\
\text { sp. }\end{array}$ & + & + & + & $\begin{array}{l}\text { walls and } \\
\text { dung }\end{array}$ & & + & + & $\mathrm{FC}^{1}, \mathrm{~F} 2$ & Tr, & $\mathrm{GP}(\mathrm{P})$ \\
\hline Siphonaptera & Ischnopsyllidae & $\begin{array}{l}\text { Myodopsylla insignis } \\
\text { (Rothschild) }\end{array}$ & & & & ex Myotis ${ }^{\star * *}$ & & & & & $\operatorname{Tr}$ & PR \\
\hline Hymenoptera & Fam. indet* & \multicolumn{9}{|c|}{ no data } & $\operatorname{Tr}$ & $?$ \\
\hline Psocoptera & Liposcelidae & $\begin{array}{c}\text { Liposcelis } \\
\text { bostrychophila }\end{array}$ & & & + & on pool & & & + & $\mathrm{CC}$ & $\operatorname{Tr}$ & $A C$ \\
\hline \multirow[t]{2}{*}{ Homoptera } & Aphidae & Trama sp. & & & + & pitfall & & & + & $\mathrm{CC}$ & $\operatorname{Tr}$ & $A C$ \\
\hline & Cixidae & Gen. et sp. indet. & & & + & old fish bones & & & + & $\mathrm{FH} 2$ & $\operatorname{Tr}$ & $A C$ \\
\hline \multirow[t]{19}{*}{ Acarina } & \multirow[t]{4}{*}{ Parasitidae } & Parasitus sp(p). & & & + & dung, timber & & + & + & $\mathrm{FC}^{\circ}, \mathrm{MC}, \mathrm{KC}$ & $\operatorname{Tr}$ & GP \\
\hline & & Eugamasus sp. & & + & + & dung, timber & & & + & $\mathrm{FC}^{\circ}, \mathrm{KC}$ & $\operatorname{Tr}$ & $\mathrm{TP}$ \\
\hline & & Vulgarogasmus sp. nr. & & & + & $\begin{array}{l}\text { porcupine } \\
\text { dung }\end{array}$ & & + & & & $\operatorname{Tr}$ & GP \\
\hline & & Gen. et. spp. indet. & + & + & + & $\begin{array}{l}\text { porcupine } \\
\text { dung }\end{array}$ & + & + & + & most sites & $\operatorname{Tr}$ & GP \\
\hline & Vegaidae & Vegaia sp. & & + & + & $\begin{array}{l}\text { dung, plant } \\
\text { litter }\end{array}$ & & & + & $\mathrm{FC}^{\circ}, \mathrm{KC}$ & $\operatorname{Tr}$ & TP \\
\hline & Zerconidae & Zerconopsis sp. & & + & & $\begin{array}{l}\text { porcupine } \\
\text { dung }\end{array}$ & & & & $\mathrm{FC}^{\circ}$ & $\operatorname{Tr}$ & GP \\
\hline & Ascidae & Arctoseius sp. & & + & + & $\begin{array}{l}\text { porcupine } \\
\text { dung }\end{array}$ & & + & + & $\mathrm{FC}^{\circ}, \mathrm{KC}$ & $\operatorname{Tr}$ & GP \\
\hline & Ameroseidae & Epicriopsis sp. & & & + & $\begin{array}{l}\text { porcupine } \\
\text { dung }\end{array}$ & & + & + & $\mathrm{CC}$ & $\operatorname{Tr}$ & GP \\
\hline & Eviphididae & Alliphis sp. & & + & + & $\begin{array}{l}\text { porcupine } \\
\text { dung }\end{array}$ & & + & + & $\mathrm{FC}^{\circ}$ & $\operatorname{Tr}$ & GP \\
\hline & Macrochelidae & Geolapsis sp. & & + & & $\begin{array}{l}\text { porcupine } \\
\text { dung }\end{array}$ & & & + & $\mathrm{FC}^{\circ}$ & $\operatorname{Tr}$ & GP \\
\hline & Spinturnicidae & Spinturnix sp. & & & & ex Myotis ${ }^{* * *}$ & & & & & $\operatorname{Tr}$ & PR \\
\hline & Macronyssidae & $\begin{array}{l}\text { Macronyssus crosbyi } \\
\text { (Ewing \& Stover) }\end{array}$ & & & & ex Myotis ${ }^{* \star *}$ & & & & & $\operatorname{Tr}$ & PR \\
\hline & Uropodidae & Gen. et sp. indet. & & + & & $\begin{array}{l}\text { porcupine } \\
\text { dung }\end{array}$ & & + & + & $\mathrm{CB}, \mathrm{WIC}, \mathrm{FC}$ & $\operatorname{Tr}$ & GP \\
\hline & \multirow[t]{2}{*}{ Eupodidae } & $\begin{array}{c}\text { Linopodes motatorius } \\
\text { (L.) }\end{array}$ & & & + & timber & & & + & $\mathrm{KC}$ & $\operatorname{Tr}, \mathrm{Cp}$ & TP \\
\hline & & Cocceupodes sp. & & & + & timber & & & + & $\mathrm{MC}$ & $\operatorname{Tr}$ & TP \\
\hline & Rhagididae & Rhagidia $\mathrm{sp}(\mathrm{p})$ & + & + & + & dung, timber & + & + & + & most sites & $\operatorname{Tr}$ & GP \\
\hline & Ereynetidae & Gen. et sp. indet. & & & + & $\begin{array}{l}\text { porcupine } \\
\text { dung }\end{array}$ & & & + & $\mathrm{CC}$ & $\operatorname{Tr}$ & GP \\
\hline & \multirow[t]{2}{*}{ Pygmephoridae } & Pygmephorus sp. & & + & & $\begin{array}{l}\text { porcupine } \\
\text { dung }\end{array}$ & & & + & $\mathrm{FC}^{\circ}$ & $\operatorname{Tr}$ & GP \\
\hline & & Bakerdania sp. & & & + & $\begin{array}{l}\text { porcupine } \\
\text { dung }\end{array}$ & & + & & FC & $\operatorname{Tr}$ & GP \\
\hline
\end{tabular}




\begin{tabular}{|c|c|c|c|c|c|c|c|c|c|c|c|c|c|}
\hline \multirow[t]{7}{*}{ Acarina } & \multirow[t]{2}{*}{ Tetranychidae } & $\begin{array}{l}\text { Bryobia praetiosa } \\
\text { (Koch) }\end{array}$ & & + & & porcupine dung & & & & + & $\mathrm{FC}^{\circ}$ & $\operatorname{Tr}$ & $A C$ \\
\hline & & Gen. et. sp. indet. & & + & + & $\begin{array}{l}\text { porcupine } \\
\text { dung, plant }\end{array}$ & & & + & & $\mathrm{HC}, \mathrm{WB}$ & $\operatorname{Tr}$ & GP \\
\hline & Hydrachnoidea & Gen et sp. indet. & & & + & stream & & & + & & KC & $\mathrm{Aq}$ & ? \\
\hline & Glycyphagidae & $\begin{array}{c}\text { Glycyphagus } \\
\text { domesticus (De Geer) }\end{array}$ & & & + & timber & & & & + & $\mathrm{MC}$ & $\mathrm{Tr}, \mathrm{Cp}$ & TP \\
\hline & Histiostmatidae & Gen et sp. indet. & & + & + & porcupine dung & & & + & & WIC, FC & $\operatorname{Tr}$ & GP \\
\hline & Acaridae & $\begin{array}{l}\text { Acarus immobilis } \\
\text { Griffiths }\end{array}$ & & & + & porcupine dung & & & + & & FC & $\operatorname{Tr}$ & $A C$ \\
\hline & Banksinomidae & Oribella sp. & & & + & porcupine dung & & & & + & CC & $\operatorname{Tr}$ & GP \\
\hline \multirow[t]{5}{*}{ Araneida } & Nesticidae & $\begin{array}{l}\text { Nesticus cellulanus } \\
\text { (Clerck) }\end{array}$ & + & & & cave wall & & + & + & & FC & $\mathrm{Tr}, \mathrm{Ad}$ & $\operatorname{TP}(P)$ \\
\hline & Tetragnathidae & Meta ovalis (Gertsch) & + & + & + & cave wall & + & + & + & + & most sites & $\mathrm{Tr}, \mathrm{Ne}$ & $\mathrm{TP}(\mathrm{P})$ \\
\hline & Dictynidae & $\begin{array}{l}\text { Circurina brevis } \\
\text { (Emerton) }\end{array}$ & + & & & scree & & & & + & WIC & $\mathrm{Tr}, \mathrm{Ne}$ & HT \\
\hline & \multirow[t]{2}{*}{ Linyphiidae } & $\begin{array}{l}\text { Sisicottus montanus } \\
\text { (Emerton) }\end{array}$ & & & + & porcupine dung & & & + & & FC & $\mathrm{Tr}, \mathrm{Ne}$ & $A C$ \\
\hline & & Grammonota sp. & & & + & porcupine dung & & & + & & $\mathrm{CB}$ & $\mathrm{Tr}, \mathrm{Ne}$ & $A C$ \\
\hline \multirow[t]{2}{*}{ Opiliones } & Phalangidae & $\begin{array}{c}\text { Oligolophus tridens (C. } \\
\text { L. Koch) }\end{array}$ & & & & scree & & & & + & WIC, $\mathrm{CC}^{*}$ & $\mathrm{Tr}, \mathrm{Ad}$ & HT \\
\hline & Sclersomatidae & Nelima elegans (Weed) & & + & + & cave wall & + & + & & + & most sites* & $\mathrm{Tr}, \mathrm{Ne}$ & $H T(P)$ \\
\hline \multirow[t]{6}{*}{ Gastropoda } & \multirow[t]{2}{*}{ Arionidae } & $\begin{array}{l}\text { Arion subfuscus } \\
\text { (Draparnaud) }\end{array}$ & + & & & cave wall & & & + & & $\mathrm{KC}$ & $\mathrm{Tr}, \mathrm{Ad}$ & $\mathrm{HT}(\mathrm{P})$ \\
\hline & & A. circumscriptus group & + & & & cave wall & & & + & + & $\begin{array}{c}\mathrm{FC}, \underset{\mathrm{KC}}{\mathrm{PT}, \mathrm{DL}} \\
\end{array}$ & $\mathrm{Tr}, \mathrm{Ad}$ & $H T(P)$ \\
\hline & Limacidae & $\begin{array}{l}\text { Deroceras laeve } \\
\text { (Müller) }\end{array}$ & + & + & & cave wall & & & + & & $\mathrm{F} 2$ & $\mathrm{Tr}, \mathrm{Cl}$ & $\mathrm{HT}(\mathrm{P})$ \\
\hline & Helicidae & Trichia hispida (L.) & + & & & cave wall & & & & + & F2 & $\mathrm{Tr}, \mathrm{Ad}$ & $\mathrm{HT}(\mathrm{P})$ \\
\hline & Zonitidae & $\begin{array}{l}\text { Zonitoides arboreus } \\
\text { (Say) }\end{array}$ & + & + & + & cave wall & & & + & + & $\mathrm{FC}, \mathrm{F} 2$ & $\mathrm{Tr}, \mathrm{Ne}$ & $\mathrm{HT}(\mathrm{P})$ \\
\hline & Endodontidae & $\begin{array}{l}\text { Discus catskillensis } \\
\text { Pilsbry }\end{array}$ & & & + & timber & & & & + & KC & $\mathrm{Tr}, \mathrm{Ne}$ & TP \\
\hline
\end{tabular}




\begin{tabular}{|c|c|c|c|c|c|c|c|c|c|c|c|c|c|}
\hline \multirow{2}{*}{$\begin{array}{l}\text { CLASS or } \\
\text { ORDER }\end{array}$} & \multirow{2}{*}{ FAMILY } & \multirow{2}{*}{ TAXON } & \multicolumn{4}{|c|}{ Habitat collected } & \multicolumn{4}{|c|}{ Seasons recorded } & \multirow{2}{*}{ Sites } & \multirow{2}{*}{\multicolumn{2}{|c|}{$\begin{array}{l}\text { Distribution } \\
\text { \& ecology }\end{array}$}} \\
\hline & & & th. & d.th. & d.z. & substrate & DJF & MAM & JJA & SON & & & \\
\hline \multirow{3}{*}{ Osteichthyes } & Salmonidae & Salvelinus fontinalis (Mitchell) & + & + & + & $\begin{array}{l}\text { limestone } \\
\text { streams }\end{array}$ & + & + & + & + & $\mathrm{DC}, \mathrm{KC}$ & $\mathrm{Aq}, \mathrm{Ne}$ & $\mathrm{HT}$ \\
\hline & Cyprinidae & Phoxinus eos (Cope) & & & + & pools & & & & & $\mathrm{HC}^{3}$ & $\mathrm{Aq}, \mathrm{Ne}$ & $\mathrm{AC}$ \\
\hline & Gasterosteidae & Pungitus pungitus (L.) & + & + & & pools & & & + & + & $\mathrm{BB}, \mathrm{HC}^{3}, \mathrm{FC}$ & $\mathrm{Aq}, \mathrm{Cl}$ & HT \\
\hline \multirow[b]{2}{*}{ Amphibia } & Plethodontidae & Plethodon cinereus (Green) & & + & & stream & & & + & & $\mathrm{MCl}$ & $\mathrm{Am}, \mathrm{Ne}$ & $\mathrm{AC}$ \\
\hline & Ranidae & $\begin{array}{c}\text { Rana clamitans melanota } \\
\text { (Rafinesque) }\end{array}$ & + & + & + & $\begin{array}{l}\text { pools, } \\
\text { streams }\end{array}$ & & & & & $\mathrm{CB}, \mathrm{HC}^{3}, \mathrm{FC}$ & $\mathrm{Am}, \mathrm{Ne}$ & $\mathrm{AC}$ \\
\hline \multirow{13}{*}{ Mammalia } & Soricidae & Sorex fumeus (Miller) & & & + & & & & & & $\mathrm{HO}^{\mathrm{a}}$ & $\mathrm{Tr}, \mathrm{Ne}$ & HT \\
\hline & \multirow{7}{*}{ Vespertilionidae } & Myotis lucifugus (LeConte) & & & + & & + & & + & + & $\begin{array}{c}\text { BB,CB,HC,WIC,FC,F2, } \\
\text { MIC,MC,PT,LCM,OV, } \\
\text { LSH,HO, HB, BC, }\end{array}$ & $\mathrm{Tr}, \mathrm{Ne}$ & HT \\
\hline & & \multirow{2}{*}{ M. septentrionalis (Trouessart) } & & & \multirow[t]{2}{*}{+} & & \multirow[t]{2}{*}{+} & \multirow[t]{2}{*}{+} & & \multirow[t]{2}{*}{+} & BB,CB,HC,FC,MIC,CC,LCM, & \multirow{2}{*}{$\mathrm{Tr}, \mathrm{Ne}$} & \multirow{2}{*}{$\mathrm{HT}$} \\
\hline & & & & & & & & & & & $\begin{array}{c}\text { GRM,OV,LSH,GM,GR,HO, } \\
\text { HB,BC, }\end{array}$ & & \\
\hline & & \multirow[t]{2}{*}{ Pipistrellus subflavus (F. Cuvier) } & & & \multirow[t]{2}{*}{+} & & \multirow[t]{2}{*}{+} & \multirow[t]{2}{*}{+} & \multirow[t]{2}{*}{+} & \multirow[t]{2}{*}{+} & $\mathrm{CB}, \mathrm{HC}, \mathrm{FC}, \mathrm{MIC}, \mathrm{CC}, \mathrm{GRM}, \mathrm{GM}$, & \multirow[t]{2}{*}{$\mathrm{Tr}, \mathrm{Ne}$} & \multirow[t]{2}{*}{$\mathrm{HT}$} \\
\hline & & & & & & & & & & & GR,KC,UL,TC & & \\
\hline & & $\begin{array}{c}\text { Eptesicus fuscus (Palisot de } \\
\text { Beauvois) }\end{array}$ & & & + & & & & & + & $\mathrm{HC}$ (sight record) & $\mathrm{Tr}, \mathrm{Ne}$ & HT \\
\hline & & $\begin{array}{c}\text { Lasionycteris } \\
\text { noctivagans (Le Conte) }\end{array}$ & & + & & & + & & & & PT (sight record) & $\mathrm{Tr}, \mathrm{Ne}$ & $\mathrm{AC}$ \\
\hline & Procyonidae & Procyon lotor (L.) & & + & + & (tracks) & & & & & $\mathrm{CB}, \mathrm{HC}, \mathrm{FC}^{\circ}$ & $\mathrm{Tr}, \mathrm{Ne}$ & $\mathrm{HT}$ \\
\hline & Mustelidae & Mustela vison Schreber & & & + & (scat) & & & & & $\mathrm{KC}^{\mathrm{a}}$ & $\mathrm{Tr}, \mathrm{Ne}$ & $A C$ \\
\hline & Castoridae & Castor canadensis Kuhl & & & + & & & & & & $\mathrm{DC}^{\star}, \mathrm{KC}^{\mathrm{a}}$ & $\mathrm{Tr}, \mathrm{Ne}$ & $\mathrm{HT}$ \\
\hline & Muridae & $\begin{array}{l}\text { Peromyscus maniculatus } \\
\text { (Wagner) }\end{array}$ & & & + & & & & & & $\mathrm{HC}, \mathrm{GM}^{\mathrm{a}}$ & $\mathrm{Tr}, \mathrm{Ne}$ & $\mathrm{HT}$ \\
\hline & Erethizontidae & Erethizon dorsatum (L.) & + & + & + & & + & + & + & + & most: except Cape Breton & $\mathrm{Tr}, \mathrm{Ne}$ & $\mathrm{HT}$ \\
\hline
\end{tabular}

Table 2: Summary of records of vertebrates from caves and mines in Nova Scotia and southern New Brunswick. [Abbreviations: th. = threshold, d.th. = deep threshold, d.z. = dark zone, Aq. = aquatic, Tr. = terrestrial, Am. = amphibian, $\mathrm{Ne}=\mathrm{Nearctic}, \mathrm{Cl}=$ circumpolar, $\mathrm{AC}=\mathrm{accidental}(\mathrm{stray}), \mathrm{HT}=$ habitual trogloxene, $\mathrm{TP}=$ troglophile, $\mathrm{GP}=$ guanophile, $(\mathrm{P})=$ parietal fauna. For key to alphanumeric site codes, see text]. [References: ${ }^{\circ}=\mathrm{Calder} \&$ Bleakney, 1965; ${ }^{3}=$ Scott, 1979; ${ }^{a}=$ McAlpine, 1979; ${ }^{*}$ Sawatzky, 1986. See McAlpine (1979) and Moseley (in press) for sources for records of bats.]

\begin{tabular}{|c|c|c|c|}
\hline Taxonomic group & $\begin{array}{c}\text { New Brunswick } \\
\text { (McAlpine 1979) }\end{array}$ & $\begin{array}{c}\text { Ontario } \\
\text { (Peck 1988) }\end{array}$ & $\begin{array}{c}\text { NS + NB } \\
\text { (this study) }\end{array}$ \\
\hline Collembola* & & $7(2 \%)$ & $25(15 \%)$ \\
\hline Coleoptera & & $15(5 \%)$ & $14(8 \%)$ \\
\hline Diptera & & $149(50 \%)$ & $33(19 \%)$ \\
\hline Other insects & & $33(11 \%)$ & $23(14 \%)$ \\
\hline TOTAL INSECTA & $54 \%$ & $204(68 \%)$ & $95(56 \%)$ \\
\hline Acari & & $8(3 \%)$ & $27(16 \%)$ \\
\hline Aranea & & $31(10 \%)$ & $5(3 \%)$ \\
\hline Opiliones & & $7(2 \%)$ & $2(1 \%)$ \\
\hline TOTAL ARACHNIDA & $22 \%$ & $46(15 \%)$ & $34(20 \%)$ \\
\hline MOLLUSCA & $4 \%$ & $21(7 \%)$ & $6(4 \%)$ \\
\hline OTHER INVERTEBRATA & $20 \%$ & $30(10 \%)$ & $35(21 \%)$ \\
\hline TOTAL INVERTEBRATES & $100 \%$ & $301(100 \%)$ & $170^{* \star}(100 \%)$ \\
\hline
\end{tabular}

Table 3: Invertebrate faunal composition of caves in eastern Canada: statistical breakdown by number of species and percentages. $\left[{ }^{*}\right.$ Collembola is included in the Insecta in order to permit comparison with McAlpine (1979). ** Accidentals are included to permit comparison of all three studies.] 